Portland State University

PDXScholar

Summer 8-3-2016

\title{
Democratization, Political Performance, and Income Distribution in Argentina and Brazil
}

Nicholas Paul Stowell

Portland State University

Follow this and additional works at: https://pdxscholar.library.pdx.edu/open_access_etds

Part of the Income Distribution Commons, and the Political Science Commons

Let us know how access to this document benefits you.

\section{Recommended Citation}

Stowell, Nicholas Paul, "Democratization, Political Performance, and Income Distribution in Argentina and Brazil" (2016). Dissertations and Theses. Paper 3157.

https://doi.org/10.15760/etd.3151

This Thesis is brought to you for free and open access. It has been accepted for inclusion in Dissertations and Theses by an authorized administrator of PDXScholar. Please contact us if we can make this document more accessible: pdxscholar@pdx.edu. 
Democratization, Political Performance, and Income Distribution in Argentina and Brazil

by

Nicholas Paul Stowell

A thesis submitted in partial fulfillment of the requirements for the degree of

Master of Arts

in

Political Science

Thesis Committee:

Birol Yesilada, Chair

David Kinsella

Bruce Gilley

Portland State University

2016 


\begin{abstract}
This research examines the effects of democratization and political performance on the functional distribution of income in Argentina and Brazil from the end of their authoritarian periods to the present. The existing literature tends to focus on the impacts of democratization and political performance on the economic growth of the country as a whole or on changes to per capita income. This analysis focuses on the equality of economic development in less developed countries because growth is not necessarily distributed equally and poverty and inequality are both endemic to many less developed countries and also negatively impact development as a whole as well as the consolidation of democracy. To examine the effects of democratization and political performance on the shape of economic development, this thesis utilizes the Polity IV index as a measure of democracy, Relative Political Extraction as a proxy for political performance, and labor's share of national income as a measure of income inequality.

Theoretically, a more democratic regime should enact policies that allow for a more equitable distribution of income because democratization increases popular representation and makes the provision of public goods preferable to the provision of private goods. Similarly, a regime with higher political capacity should be better equipped to enact whatever policies and development strategies it chooses, thereby reducing income inequality if the regime deems equitable development a priority.
\end{abstract}


The main finding of this research is that political performance has had a significant impact on the shape of economic development in Argentina and Brazil, whereas the effect of democratization on the shape of development is less clear. A stronger, more effectively performing government will be better able to deliver equitable development regardless of its level of democracy than will a poorly performing government of any type. 


\section{Table of Contents}

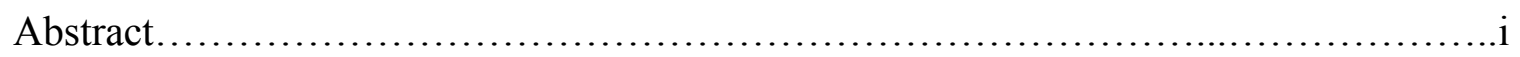

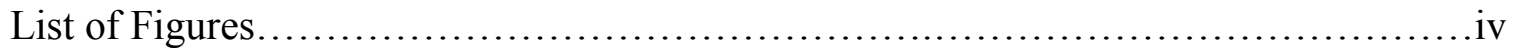

Chapter 1

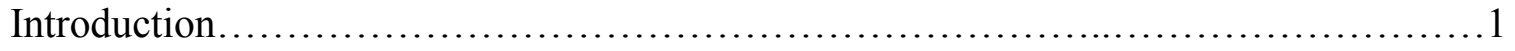

Chapter 2

Literature Review.............................................................4

Chapter 3

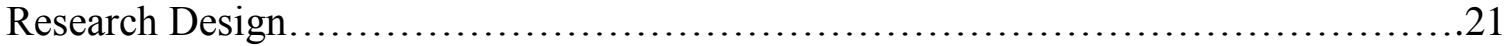

Chapter 4

Findings and Analysis.............................................................

Chapter 5

Conclusion............................................................99

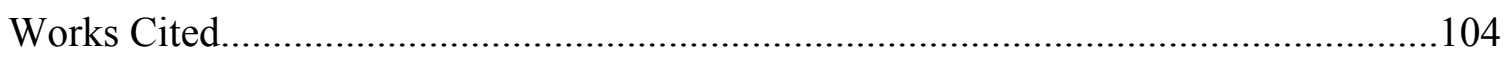




\section{List of Figures}

Figure 4.1 - Polity IV Scores for Argentina and Brazil..............................39

Figure 4.2 - Political Performance of Argentina's Authoritarian Regime...............40

Figure 4.3 - Political Performance of Brazil's Authoritarian Regime..................41

Figure 4.4 - IADB Structural Reform Index................................43

Figure 4.5 - Political Performance of Transition Period: Argentina....................48

Figure 4.6 - Political Performance of Transition Period: Brazil........................48

Figure 4.7 - IADB Structural Reform Index.................................49

Figure 4.8 - Political Performance of Menem Regime............................57

Figure 4.9 - Political Capacity from Collor to Franco............................59

Figure 4.10 - Political Capacity of the Cardoso Regime...........................60

Figure 4.11 - Corruption in Argentina........................................61

Figure 4.12 - Corruption in Brazil..........................................64

Figure 4.13 - Economic Liberalization of the Menem Regime........................65

Figure 4.14 - Economic Liberalization from Collor to Cardoso......................66

Figure 4.15 - Labor's Share of National Income...............................69

Figure 4.16 - RPE during Kirchner Regime...................................78

Figure 4.17 - RPE of Kirchner and Lula Regimes...............................79

Figure 4.18 - Corruption of Kirchner and Lula Regimes...........................80

Figure 4.19 - Economic Openness from Cardoso to Lula..........................84

Figure 4.20 - Economic Openness of Kirchner and Lula Regimes....................85 
Figure 4.21 - Functional Income Distribution of Kirchner Regime...................87

Figure 4.22 - Functional Income Distribution from Cardoso to Lula...................88

Figure 4.23 - LS4 of Argentina and Brazil Compared............................91

Figure 4.24 - Political Performance and Income Distribution......................95

Figure 4.25 - Corruption and Labor's Share of National Income....................97 


\section{Chapter - 1 \\ Introduction}

From 1974 through the 1980s there was an emergence of new democracies throughout the world known as the Third Wave of democratization. Many of these transitions occurred in poor or developing countries in the context of significant poverty, inequality, and economic crisis. Now that several decades have passed, it has become possible to examine the effect that democratization has had on the shape of development in some of these countries. Is it the type of regime or its political capacity that has a greater effect on income inequality in underdeveloped countries? To address this question, this thesis looks at the level of democracy, the political performance, and the functional income distribution in Argentina and Brazil from the breakdown of their respective authoritarian regimes to the present.

The effect of democratization on economic growth has been thoroughly covered in the literature, but its effect on development is generally limited to an examination of per capita GDP. Thus there is a dearth of literature with a focus on the effect of democracy on the shape of economic development--the winners and losers. Put another way, the existing literature tends to focus on the change in average wealth within a country rather than the effects democratization may have on specific sectors of the economy. Given that the wave of democratic transition brought with it a hope for the alleviation of extreme poverty and inequality, it is important to evaluate this relationship. 
This study will attempt to examine the effect that democratic transition has had on the shape of development by looking at Argentina and Brazil from their authoritarian periods up to the present. In addition to the qualitative and contextual evidence available in the existing literature, it will utilize several indices descriptively to trace changes in each country over time and to compare the cases to each other. For regime type, this study will use the Polity IV index. It will use Relative Political Extraction as a proxy measure for political performance. Additionally, it will use the Transparency International Corruption Perception Index (CPI) to look at corruption and its relationship to democracy and political performance. It will also use the Inter-American Development Bank's Structural Reform Index (SRI) to look at any effect that development strategy could have on the shape of economic development. Finally, it will use data derived from the United Nations National Accounts Statistics and the International Labor Organization's Yearbooks of Labor Statistics to chart the functional income distribution and its change from period to period.

The central argument of this study is that in Argentina and Brazil, the degree of governance has had a more significant effect on development than has the level of democracy. A regime comprised of weak, incapable institutions will have trouble affecting broad, equitable development regardless of how democratic it is. This argument is confirmed by the findings to be presented in this paper which show that, despite successful democratization and likely consolidation of democracy, neither Argentina nor Brazil have alleviated the epidemic of extreme inequality or altered their respective 
economies toward a more equitable income distribution. Only after political capacity improved did either country begin a move toward more equitable economic development.

This thesis is organized in the following manner: Chapter 2 reviews the existing literature related to democracy, political performance, and development. It covers the neoliberal economic development model--the dominant model throughout the Third Wave of democratization--and its relationship to democracy and development. It then reviews the body of literature pertaining to structural and institutional factors affecting development with a focus on political performance. Chapter 3 proposes the research design to be used in this study. Chapter 4 reports the findings of this research. It traces Argentina and Brazil from their respective authoritarian periods, through their transitions and to the present with a focus on regime type, political performance, and income distribution. Chapter 5 discusses the findings, addresses limitations to this research, discusses policy implications, and offers potential areas of further research. 


\section{Chapter - 2 Literature Review}

The Third Wave of democratization, which began with Portugal's Carnation Revolution in 1974, brought transitions toward democracy in many Less Developed Countries (LDCs), particularly in Latin America and the Asian Pacific in the 1980s. These emerging democratic regimes were faced with the trilemma of confronting fiscal crisis and promoting economic growth and equitable development without damaging their new and fragile democracies. They needed to choose economic policies that would foster steady, long term, equitable growth without damaging their popular legitimacy and risking a slide back into authoritarianism. They needed a developmental strategy that would lift their most vulnerable populations out of poverty and set their countries on a path to prosperity in an increasingly global economy. They needed to tackle the legacy of poverty and extreme inequality often inherited from the era of authoritarianism. They needed to do so through their emerging democratic institutions.

What is the relationship between democratization and the shape of economic development in LDCs? The Third Wave democracies tended toward developmental strategies in line with neoliberalism and the Washington Consensus. The policies related to this developmental model promised to curb inflation and stabilize the economy, foster economic growth, and lift the LDCs out of situations of endemic poverty and inequality. Countries that followed this path had varying degrees of success. In Latin America the 
Washington Consensus is seen to have been a failure with regard to reducing poverty and inequality and performed poorly at staving off fiscal crisis and hyperinflation in the 1980s and 1990s (Arestis 2004; Bresser Pereira 1993; Moreno-Brid et. al. 2004). What explains this poor performance? There is also significant variance in outcomes between countries within the region despite similar conditions and external pressures. What accounts for this variance?

This chapter reviews the existing literature regarding the relationship between democracy, degree of governance, and economic development. It begins with an overview of neoliberalism and the Washington Consensus. It traces competing arguments regarding the relationship between democracy and neoliberal economic reforms. From there it reviews developmental strategies from Social-Democratic and institutional perspectives. It then goes into the institutional and structural factors of democracy that affect policy choices and shape development. It concludes with a review of Political Performance and its relationship to the extraction and allocation of resources that determine a country's economic trajectory.

\section{Neoliberal Economic Development and the Washington Consensus}

Economic neoliberalism, which dominated global economic and developmental ideology during the Third Wave of democratization, takes as its starting point the primacy of individual liberty and the belief that economic freedom is a necessary 
condition for political freedom (Friedman 1962). The neoliberal development model, which was promoted by Milton Friedman and advocated by Margaret Thatcher and Ronald Reagan, the International Monetary Fund (IMF) and the World Bank, "the Federal Reserve, the U.S. Treasury, the finance ministries of the G-7 countries, and the chairmen of the twenty most important commercial banks" (Bresser Pereira et. al. 1993: 19), swept through the Third Wave countries of Asia and Latin America in the 1980s and 1990s. An understanding of this ideology is therefore central to the analysis of economic development in LDCs through the 1980s.

Neoliberalism's policy agenda, which was coined by World Bank economist John Williamson as the "Washington Consensus," includes ten general policy prescriptions based on reliance on markets exclusively to bring about efficient reallocation of resources $^{1}$. The common theme of the Washington Consensus and neoliberal development strategy is the reduction of the role of the state through strategies such as deregulation and privatization. Compared to the import-substitution-industrialization (ISI) model which was common in Third Wave democracies in Latin America and Asia, neoliberalism suggests a much smaller role for the state (Griffin 1989). The pertinent questions regarding the neoliberal development strategy would be how such policy prescriptions would affect the shape of economic development in poorer countries and

\footnotetext{
${ }^{1}$ These policies include: (1) control of fiscal deficits, (2) reorientation of public expenditure priorities, (3) tax reform with an emphasis on a broad base and moderate rates, (4) allowing markets to determine interest rates, (5) allowing markets to determine exchange rates, (6) outward-oriented trade liberalization, (7) liberalization of finance, especially Foreign Direct Investment (FDI), (8) privatization of state-owned enterprises, (9) economic deregulation, and (10) security of property rights (Kingstone 2011:29).
} 
how such a developmental model would be implemented through new and fragile democratic institutions.

\section{Neoliberalism and Democracy}

The literature contains significant debate as to the relationship between neoliberal economic reform and the democratic process, particularly regarding new, fragile democracies of the Third Wave. Arguments for the existence of a positive relationship point to the reelection of presidents who had implemented neoliberal reforms ${ }^{2}$ and polling data showing popular preference for markets over the state in certain realms (Kingstone 2011).

Neoliberalism's advocates also suggest that the Washington Consensus' focus on curbing inflation creates a political and democratic base of support because inflation disproportionately hurts the more broad, less wealthy segment of the populations in question (Weyland 2004). The counter argument to this claim is that, while the Washington Consensus focuses on inflation, it tends to ignore and arguably increase unemployment. It is argued that when faced with bleak economic prospects, populations tend to be overwhelmingly more concerned with job security than the price of goods and services (Bresser Pereira et. al. 1993). Therefore, the common arguments for a positive

\footnotetext{
${ }^{2}$ Menem in Argentina and Cardoso in Brazil are two such examples.
} 
relationship between neoliberal economic reform and democracy are not entirely convincing.

\section{Neoliberalism Against Democracy}

There are a number of common arguments that neoliberal development is at odds with democracy. The first is that neoliberalism is too often imposed from abroad, both directly and indirectly. The direct route of "neoliberalism from abroad" flows through international financial institutions (IFIs) such as the IMF, the World Bank, and other private international investment groups. Examples of such impositions include Mexico's 1982 debt default and Bolivia's bout with hyperinflation in 1985. In both cases, the executives were compelled to turn toward neoliberal reforms in order to gain new financing (Bresser Pereira et. al. 1993; Kingstone 2011). Neoliberalism is also imposed from abroad in an indirect way through globalization and the decentralization of global finance. The fact that the economic model du jour is neoliberal indirectly pressures poor governments to follow suit, particularly with the rapid spread of global finance in the 1980s and 1990s. This occurs regardless of the best interests of the country in crisis.

A second, perhaps more persuasive argument pitting neoliberal economic reforms against democracy is the phenomenon of "neoliberalism by surprise," in which politicians seem to conceal their true agenda while running for office, only to switch course once elected. They do so because of neoliberalism's significant social cost and associated political opposition (Pereira et. al. 1993). A few examples of this sort of political bait- 
and-switch include Menem in Argentina, Paz Estenssoro in Bolivia, Fujimori in Peru, and Andres Perez in Venezuela.

These arguments for an incongruence between democracy and neoliberalism are not uniformly accepted. Leslie Armijo and Philippe Faucher (2002) examine Chile, Argentina, Brazil, and Mexico from 1970 to 1999 and find that external economic assistance such as IMF and World Bank loan packages have no effect on the economic reforms in their sample. They also find that political insulation does not affect the likelihood of pro-market reform. Most importantly, they find that pro-market reforms must be preceded by shifts in elite preferences, and shifts in popular preferences in the case of democracies.

It is also argued that neoliberal economic reforms weaken democratic institutions and processes by exacerbating the tendency toward delegative democracy--a system in which elected leaders are expected to solve problems without a need for transparency and accountability (Bresser Pereira et. al. 1993). This is particularly true in time of crisis. Haggard and Kaufman (2008) demonstrate that economic crisis increases the influence of technocrats vis-a-vis voters, unions, and other economic stakeholders. Given that the LDC shift toward neoliberal economics occurred largely in the crisis-rich period of the 1980s and early 1990s as opposed to times of robust and stable economies, Westerninfluenced technocrats likely played an outsized role in the shift.

Perhaps the most damning argument against a positive relationship between neoliberal development and democracy is the fact that the purest examples of this 
development model have happened coercively. Griffin (1989) evaluates alternative development strategies on a number of criteria including level of democracy and finds no correlation between regime type and development strategy except at the margins, where he sees Friedman-style monetarism. He cites Pinochet's Chile as the purest example of a monetarist strategy, which occurred necessarily under a brutally coercive authoritarian regime.

\section{Neoliberalism and Equitable Development}

How does the neoliberal economic model affect the shape of development in the forms of equality and human capital? Griffin (1989) examines the relationship between the neoliberal or "monetarist" development model and human capital formation in the forms of health, nutrition, job skills, and education, and finds that the neoliberal or monetarist developmental strategy performs much more poorly than alternative strategies such as ISI, Communism, or redistributive strategies of development. Others agree (Bresser Pereira 1993; Stiglitz 2011).

Griffin also argues that monetarism performs poorly at alleviating poverty and inequality because neoliberal reforms tend to promote capital-intensive growth and tend to neglect land reform, whereas labor-intensive growth and land reform are viewed as keys to the reduction of poverty and inequality. In short, the Washington Consensus may be seen as a failure with regard to equitable development and the alleviation of poverty and inequality, particularly in Latin America (Moreno-Brid 2004) 


\section{Structural and Institutional Factors Affecting Development}

Much of the literature argues that successful growth and development depend less on the specific developmental strategy chosen than on the quality and shape of institutions through which policy choices are made. In this sense, there is "no best path to development," (Griffin 1989: 236); weak institutions will hinder any development strategy. It is thus arguable that the failures of the neoliberal economic strategy in LDCs are a result of institutional weakness rather than flaws in the strategies themselves. How, then, do institutional factors affect policy choices, the allocation of resources, poverty, and inequality?

Modernization Theory as posited by Seymour Martin Lipset (1959) and confirmed by Przeworski and Limongi (1997) tackles the question of how economic development affects democracy and demonstrates that economic development at least sustains democracy where it already exists. The theory suggests that as societies become more urban, wealthy, and educated, a middle class grows, the cost of transmitting information decreases, and civil society flourishes and demands representation through democratic institutions. But how does democracy affect development? How do regime characteristics affect developmental strategies and economic policy choices?

Haggard and Kaufman (2008) examine the effect of democratization on responsiveness of governments to the interests of low-income groups and find that 
democracy has had no general impact on social spending, arguing that this is because new democracies face a number of political and economic constraints. They do find, however, that new democracies in Latin America tended to opt for more targeted antipoverty reforms than their authoritarian predecessors, which opted for shallow, wide ranging reforms. They also indicate that targeted anti-poverty programs are preferred by the World Bank and the Washington Consensus over broad social safety nets, which seems to confirm the earlier argument for neoliberalism imposed from abroad.

As expected, economic crisis has a profound effect on politics, and specifically economic policy, leading to radical, disruptive reforms (Haggard and Kaufman 2008). It also increases the relative influence of technocrats as previously discussed, and undermines institutional foundations. In the reverse direction of the crisis-politics relationship, it is found that democracy reduces the incidence of economic crisis because competition causes moderation of policy through veto points, checks, and balances (Tseblis 1995; Armijo and Gervasoni 2010).

While external factors indeed play a role in growth and development, their effect on economic policy choices should not be overstated. Through an examination of nineteen Latin American countries from 1982 through 1998, Remmer (2002) finds that internal politics matter significantly more than external factors. In particular, she finds that unionization and government partisanship have a much greater influence on policy than does the external economic environment. 
While some explanations of the structural effects on growth and development focus on inter-party politics and labor organizations, others focus more directly on political institutions themselves and how these institutions affect resource allocation and thus development. Bruce Bueno de Mesquita et. al. (2002) use formal theoretical modeling to argue that a more democratic regime will make the provision of public goods more favorable relative to private goods. This is because the elected leader owes her success to a larger group (those that voted for her, the "winning coalition") than does an autocrat, making the provision of public goods a more attractive way to produce value for that group. Bueno de Mesquita et. al. then confirm this theoretical argument through a wealth of empirical evidence which demonstrates that democracies provide more public goods than autocracies. They find that income, growth, investment, civil liberties, property rights, government transparency, and a host of public health, education, and social security measures all increase as the size of the winning coalition increases. When an executive requires a larger group in order to gain or retain her position, developmental policies should be more equitable. Democracy should positively affect equality according to this argument.

\section{Assessing Political Performance}

While the previous section surveyed the literature on democracy and its relationship to economic reforms and strategies, this section examines political performance itself, independent of regime type. As much of the literature reviewed 
above argues, the strength of political and economic institutions is a strong determinant of the effectiveness of economic development. Put another way, political performance strongly affects economic performance.

The degree of governance or performance of political institutions are not intrinsically linked with the type of regime in power. Only recently, however, has political science undergone an attempt to systematically analyze and compare states based on political performance across regime types and indifferent to them. Regardless of the internal process of policy formation, policy choices must be implemented through political institutions which can vary in effectiveness. The capacity of these institutions in turn affect to some extent the trajectory of a country's growth and development. In order to measure and compare the political performance independent of regime type, Kugler and Tammen (2012) develop a dynamic index: Relative Political Capacity (RPC). Their aim is "to provide a workable approximation of the effect of policy choices on economic growth on a national level" (Kugler and Tammen 2012: 49).

RPC is divided into three component indexes: Relative Political Extraction (RPE), Relative Political Reach (RPR), and Relative Political Allocation (RPA) (Kugler and Tammen 2012). This is a novel way to conceptualize the aim of governments. They extract resources from their populations, usually in the form of taxes. They seek to "reach" or have access to as much of their population as possible. Finally, they decide how to allocate the resources that they have extracted from the population that was within their reach. These three components interact to determine the political capacity of a 
government. A regime's political capacity theoretically affects its economic health, including incidence of poverty and level of inequality.

LDCs, particularly the new democracies of the Third Wave, tend toward newer and weaker political institutions than the rich, time-tested democracies of Western Europe and North America. The relative ability of a developing country to extract resources from its population will affect the government's ability to resist upheaval-which is crucial in a new democracy--and to perform its other essential functions such as facilitating growth and development. Extraction is therefore a central issue to newer, more fragile, and less developed polities. Implementing a growth-facilitating tax system should thus be the central concern in developing countries. RPE is a method of measuring and comparing states' abilities to extract these necessary resources from their populations.

Political reach is also a principal problem in most LDCs. In order to extract the necessary revenue, a government must be able to reach a sufficient segment of the population. Institutions such as independent courts and the rule of law are instrumental in determining what portion of the population is actually being governed by the political regime in rule. Weak institutions and low RPR contribute to the manifestation of expansive informal economic sectors of the LDCs throughout Latin America. Low levels of RPR as seen in weak rule of law and ill-defined property rights are argued to stunt the ability of LDCs to develop and prosper, contributing to the plight of the lower strata of the population (de Soto 2000). In countries in which the underground economy prevails, 
governments suffer from weak political capacity due to the failure to extract resources and cannot generate revenue that provides productivity-enhancing public goods. In circumstances like this, a vicious cycle of underdevelopment repeats itself." (Kugler and Tammen 2012: 57-8). Commerce exists in even the most underdeveloped regions of the world; societies depend upon it. However, if governments lack the capacity to tap into the local marketplace, they may fail to extract the resources necessary to perform. While the interactive effects of RPR, RPE, and RPA are still unknown, it is intuitive that political reach and extraction are related.

After reach and extraction comes the problem of allocation. The determination of how to allocate resources requires the balancing of current and future benefits, economic prosperity and political stability, and is always constrained by the desire of political elites to retain office. The added influence of political alignments, welfare legacies, and the global and regional economic environment makes certain that allocative decisions are complex and multifaceted. Of course, once the decision on how to allocate resources is made, there is the issue of policy implementation, which is reflective of the strength and effectiveness of the institutions responsible for resource distribution. As RPC is mostly concerned with economic growth, its allocation component compares how resources are used relative to how they would theoretically be used to maximize economic growth, fully aware that growth is not the only goal of government allocation (Tammen 2000).

Government allocation may be weighted either toward the provision of public goods or private goods. This component of RPC is therefore most closely tied with 
corruption in the form of the clientelistic distribution of private goods to those that helped political elite achieve or retain power, also known as patronage. The literature suggests several factors that affect the incidence of patronage. First, and as previously mentioned, the more narrow an incumbent base, the greater the incidence of patronage (Bueno de Mesquita et. al. 2002). This fact is confirmed by Karen Remmer (2007). By examining Argentina from 1983-2003, and operationalizing patronage as increase in administrative spending in total, per capita, and as a percentage of GDP, Remmer determines that poverty and non-tax revenue such as foreign aid or natural resources also increase patronage. That poverty increases the inefficiency of resource allocation suggests an important reason to seek to reduce poverty: poverty hurts political performance. That foreign aid actually affects the efficiency of political allocation negatively suggests that foreign aid may work at cross purposes with regard to development, an interesting and counterintuitive finding.

In sum, the extent to which governments are able to reach out to their populations, the effectiveness with which the extract resources therefrom, and the ways in which they reallocate those resources have profound implications for how their countries grow and develop. Policy choices result from a complex web of competing forces, many of which are independent of regime type, and the success of their implementation depends largely upon the capacity of political institutions. 
This chapter has reviewed the literature pertaining to the relationship between democracy and economic development in Third Wave democracies of the underdeveloped world. It has examined the basis behind the Washington Consensus and corresponding neoliberal economic development model. It has reviewed the cases for and against the relationship between neoliberal economic reforms and democracy and shown that both sides have merit. That said, the literature does seem to suggest some glaring weakness with regard to economic neoliberalism. In particular, the monetarist development strategies tend to increase unemployment and may actually contribute to economic crisis in LDCs with weak political and economic institutions.

The strength of political institutions seems to be a crucial factor in fostering economic growth and equitable development. The literature suggests that the developmental strategies chosen are less important than the institutions through which they are carried out. Most sides seem to agree that economic reform will be most effective in providing the most good for the most people if developed through democratic institutions with ample participation and transparency.

The literature highlights that the allocation of resources is a strong determinant of the success of economic growth and development. However, allocative choices and their implementation are affected by a large number of complex, interacting, and competing forces. Democracy plays some role in these choices, but so do economic constraints, stakeholder preferences, welfare legacies, the partisanship of those in office, labor unionization, international financial institutions, globalization, foreign aid, and 
ideological trends. In short, the effects of democracy on development--and particularly on poverty and inequality--are unclear. Perhaps it is not the level of democracy that determines the ability of a country to develop, but rather the capacity of its government-regardless of regime type--to perform the functions necessary for sustained growth and equitable development.

This thesis focuses on how democratization and political performance have affected economic development in two LDCs--Argentina and Brazil. Much of the existing literature focuses on economic growth and tends to ignore the relationship between politics and development with a focus on inequality. This thesis will use the cases of Argentina and Brazil beginning with the breakdown of their authoritarian regimes in the 1980s. In order to examine the relationship, this thesis will use functional income distribution as its dependent variable, measured as Labor's share of national income. It will use the Polity IV index to measure the level of democracy, as is common in the literature. To approximate political performance it will use RPE. As a component of institutional performance it will utilize Transparency International's Corruption Perception Index. It will also examine the extent to which each regime adhered to a neoliberal development strategy. This will be done using the structural reform index developed by Eduardo Lora (2012) of the Inter-American Development Bank.

Based on this literature review, it can be concluded that there are conflicting arguments concerning the relationship between political development, economic 
development, and functional income distribution. The next chapter will provide the research design that is used in this study to analyze this relationship. 


\section{Chapter - 3 \\ Research Design}

As previously stated, the existing literature lacks a consensus with regard to the effects of democratization and political performance on the distribution of income in developing countries. The purpose of this chapter is to propose a research design that sheds light on this relationship. First, it will introduce and justify the cases to be examined and analyzed. It will then propose a theory based on the existing literature. From there, it will explain and operationalize the variables that will be used in the research and justify a model of analysis that should lead to meaningful conclusions with regard to the question at hand. Based on the literature previously presented, this research will examine how democratization and political performance affect economic development in two Third Wave LDCs, Argentina and Brazil, employing the research design explained below. In doing so, it will address how an increase in the level of democracy or degree of governance affects the equitability of economic development. This research should speak to the quality of democracy as well as to the performance of regimes regardless of level of democracy. 


\section{The Cases}

This research will take the form of a case study of Argentina and Brazil. There are a number of reasons for using these cases in an analysis of the relationship between democracy and income distribution. Brazil and Argentina were each "third wave" democratizers. Argentina began the process in 1983 with the breakdown of its military regime following economic crisis and the disastrous war over the Falkland Islands. Brazil began a more gradual transition from military government toward democracy in 1982 with direct elections of all state governors and eventually a civilian president in 1985 . Argentina and Brazil possess the two largest economies in South America. For these reasons, they are each referred to as "strategic swing states" in democratization literature (Diamond 2009). Their size and location also somewhat minimize the influence of the United States on their economic policy, which is important because this analysis is examining internal factors and therefore benefits from as little external influence as possible. This makes Argentina and Brazil better candidates for this study than a country closer to the United States such as Mexico or a smaller, more economically dependent country such as the Dominican Republic. Finally, given that poverty and inequality are at the heart of an examination of functional income distribution, it seems crucial to examine less developed countries. Latin America is generally underdeveloped and suffers from relatively immense poverty, inequality, and associated health concerns. Brazil and Argentina are not exceptions to these regional phenomena. Therefore, Argentina and 
Brazil seem to be reasonable cases for studying the effects of democratization on income distribution in LDCs and emerging markets.

Given the fact that the level of democracy is of primary concern, this research will focus on each case beginning with their late authoritarian periods, through democratization, and leading to the present. Argentina democratized in 1983 and Brazil began democratization in 1985, so this research will begin its examination in 1980. By doing so it will capture development in both highly authoritarian and relatively democratic periods as well as the periods of transition.

This research will therefore begin in the early 1980s. It will engage in a detailed examination of Argentina and Brazil with a focus on events leading to significant changes in each case's level of democracy and the periods that followed such changes. It will compare income distributions in the authoritarian period to the transition and consolidation phases in an attempt to gain insight on the relationship between democratization and inequality. It will also examine dynamic changes to political performance so as to determine whether political performance is a stronger factor in determining functional income distribution than is regime type. It will also pay acute attention to stark changes in development strategy, economic policy, and financial policy in the various periods of democratization. Ideally, what will emerge from this case study is a clearer picture of the effects that democratization and political performance have on functional income inequality in two developing Latin American countries. 


\section{Theoretical Perspective}

This study will be based on the structural and institutional theoretical perspectives outlined in the previous chapter. From this perspective, an increase in the quality of democratic institutions should cause an increase in the equality of economic development through an increase in veto points in policy formation (Tsebelis 1995), as well as an increased incentive for political elites to provide public rather than private goods due to an increase in the winning coalition relative to that of the selectorate (Bueno de Mesquita 2002). Theoretically, an increase in the level of democracy should therefore increase popular representation. As larger and therefore poorer segments of the population increasingly affect policy choices, those policies should lead to more favorable outcomes for more people. However, a poor, poorly performing, or corrupt democracy may be simply unable to effectively implement broadly popular and beneficial economic policy when it so chooses (Haggard and Kaufman 2008). Therefore, this research will also be using the theoretical framework of Kugler and Tammen (2012) to examine the effect of political performance, independent of the level of democracy, on equitable development. Regarding economic development, this research will follow the conceptual framework of Guerrero (2012), who developed measures of functional income distribution based on labor's share of national income.

Based on identified key concepts in the literature, the key question to be tested is: How is labor's share of national income affected the level of democracy, political 
performance, corruption, and the type of development strategy chosen by the elites? The following hypotheses are considered to examine this question:

H1: An increase in the level of democracy positively affects labor's share of national income

HOa: The level of democracy is unrelated to labor's share of national income

H2: An increase in political performance positively affects labor's share of national income

H0b: Political performance is unrelated to labor's share of national income

In order to test these hypotheses, key concepts such as the level of democracy, political performance, and functional income distribution need to be operationalized through key variables.

\section{Key Variables}

\section{Economic Development}

This thesis is concerned with the ways in which democratization and degree of governance affect the shape of economic development. Rather than using a simple measure such as GDP per capita which merely captures the increasing income of the 
"average" member of a population, this thesis will concern itself with equality of economic development. It will do so because inequality is a significant and common feature of many of the less developed Third Wave democracies. Moreover, income inequality is a feature that is argued to stifle human development, public health, economic growth, and the consolidation of democracy itself (Wilkinson and Pickett 2010). Therefore, the dependent variable of this research will be the functional distribution of income.

This thesis will focus specifically on labor's factor share of national income. There are several reasons for the use of labor's factor share of national income as the dependent variable in this research. Guerriero (2012) suggests at least three such reasons. First, an examination of the functional distribution of income can help connect macroeconomic measures with incomes at the household level. Second, such a study can aid in the understanding of income inequality. This relationship between factor shares and income inequality is complex, but factor income distribution may be an important determinant of personal income distribution given that wealth and capital tend to be more unequally distributed than income (Piketty 2013). Third, factor shares are relevant to the addressing of certain social justice concerns. For instance, there is an arguable link between employer profits and employee perception of "fair" wages (Guerriero 2012: 34). Of particular interest to this research, it is found that there has been a general, global decline in labor's factor share of income since the mid-1980s, corresponding with the third wave of democratization as well as the rise of the neoliberal economic model. It is 
also crucial to this research to note that despite the common assumption of classical economic theorists, factor income shares are not directly related to stages of economic development once self-employment is properly accounted for (Guerriero 2012: 13). Therefore, changes in factor income shares are more likely to be an effect of policy choices and implementation than of national wealth.

Labor share (LS) is broadly defined as the percent of national income which accrues to labor or, in other words, total compensation of employees divided by national income. The use of total employee compensation rather than merely wages and salaries is preferred because it includes the non-wage forms of payment like tips, bonuses, and employer contributions to pensions and social security.

There are two main interrelated conceptual issues with regard to capturing LS. The first is that labor and capital are not so neatly divided in practice as they are in theory. In fact many if not most individuals and households tend to derive their income from a number of different sources. The totality of one household's earnings cannot be neatly categorized as either labor or capital. The second issue in conceptualizing LS is how determine the share of self-employment income that constitutes labor income. Selfemployment is especially concerning in the assessment of developing countries, where the informal economy and self-employment tend to be relatively prevalent. "In developing countries labor income is badly understated by the employees' compensation measure, which also risks changing significantly only as a consequence of a possible trend away from informal employment" (Guerriero 2012: 5). 
Capturing self-employment within LS is therefore crucial. However, there is no consensus as to how much of self-employment income should count toward labor income. For instance, while Johnson (1954) attributes roughly two thirds of selfemployment income to labor, Kravis (1959) suggests that virtually all self-employment income in developing countries comes from labor services. Perhaps more reasonably, self-employment income can be assumed to take on the same labor/capital ratio as the rest of the economy (Harrison 2002). Following the work of Guerriero (2012) this research uses three measures of $\mathrm{LS}^{3}$ :

$$
\begin{aligned}
& \text { LS (unadjusted) or LS1 }=\frac{\text { compensation of employees }}{\text { Value added (- indirect taxes - fixed capital) }} \\
& \text { LS4 }=\frac{\text { compensation of employees }}{\text { Value added (- indirect taxes - fixed capital) }- \text { mixed income }} \\
& \text { LS6 }=\frac{\frac{\text { compensation of employees }}{\text { number of employees }} \cdot(\text { total worforce }- \text { employers })}{\text { Value added (-indirect taxes - fixed capital) }}
\end{aligned}
$$

${ }^{3}$ Guerrero (2012) developed six different measures of LS, labeled LS through LS6. This research utilizes the three measures (LS1, LS4, and LS6) for which the most data are available pertaining to Argentina and Brazil. It retains the original labels for each measure to remain consistent with Guerrero's original work. 
LS1 is the unadjusted measure of labor's factor share. It entirely ignores selfemployment. LS4 treats self-employment income as if it follows the same labor-to-capital income ratio as the rest of the economy. While oversimplified, it improves on the unadjusted LS by conceding that self-employment income includes at least some amount of capital income. Guerriero argues that LS6 is the most accurate measure of labor's factor share. It incorporates self-employment income by attributing the average employee's earnings to the entire workforce less the employers. It assumes that those members of the labor force who are not employers tend to earn similarly whether they are employees, self-employed, or family workers. The denominator of each measure subtracts indirect taxes and fixed capital from total value added because they go neither toward labor compensation nor capital gains. This adjustment to value added will only take place for years where data on indirect taxes and fixed capital are available.

The data used to compute the three LS measures in this research are retrieved from the United Nations National Accounts Statistics (UNNAS) database and the International Labor Organization (ILO) Yearbooks of Labor Statistics. The UNNAS database provides yearly data collected for 178 countries since 1946. The ILO Yearbooks of Labor Statistics include country profiles and statistics on almost 200 countries from 1969 onward. They provide data on the workforce based on many factors including the International Classification of Status in Employment (ICSE-1993)--from which the numerators of the LS equations shall be derived. It must be noted that while the three measures of LS will differ, we are less concerned with the absolute value of LS than its 
change over time. Given the fact that the three LS measures follow the same dynamic trend it is less crucial which specific LS measure are employed.

\section{Level of Democracy: Polity IV}

The primary independent variable for this thesis is the level of democracy. It will be quantified through the use of the Polity IV index. The index is part of the Polity Project started by the Center for Systemic Peace. It covers 167 countries from 1800 through 2013. It provides a "polity score" for each country for each year ranging from 10 to +10 with -10 representing hereditary monarchy and +10 representing consolidated democracy. Polity scores are also divided into three main regime categories. Scores between -10 and -6 are categorized as "autocracies," scores between -5 and +5 are categorized as "anocracies," and scores from +6 through +10 are categorized as "democracies." Polity IV uses six component measures to capture information on three features of government: executive recruitment, constraints on executive authority, and political competition. Its focus is on central governments (The Polity Project).

Polity IV also suffers from some criticism. Components such as "constraints on the chief executive," while crucial to the measurement of the level of democracy, are difficult to measure. Beyond measurement issues, Polity IV also arguably suffers from the problems of redundancy and convoluted aggregation rules (Munck and Verkuilen 2002). Also, compared to other indices such as the Freedom House Index, which incorporates civil liberties and political participation, Polity IV offers a rather minimalist 
definition of democracy. Perhaps the most robust criticism of Polity IV as well as measures such as the Freedom House Index suggests that these indexes fail to capture the difference between genuine and defective democracies and argues that many of the Third Wave democracies are stable, yet defective (Merkel 2004). The basis of this argument is that elections and democratic procedures are not sufficient conditions for embedded, liberal democracy. According to this argument, a genuine, embedded democracy also requires strong political and civil rights and horizontal accountability. Polity IV is argued to neglect these features.

Despite these drawbacks, Polity IV is a relatively high quality measure of the level of democracy. It offers clear and detailed coding rules, tests of intercoder reliability, and its disaggregated data are publicly available (Munck and Verkuilen 2002). It is widely used throughout democratization literature. For example, Acre and Bellinger (2011) use the Polity IV index to show that protests in Latin America increase with economic liberalization in democratic settings, and Jong-A-Ping and Haan (2011) use the index to examine how regime type and duration affect the acceleration of economic growth. It is favorable to the Freedom House Index because Polity IV offers a single score rather than two scores. It has a narrower and more minimalist definition of democracy which emphasizes reliability and consistency compared to the more maximalist approach of Freedom House (McMahon and Kornheiser 2010). Therefore, the Polity IV index should be an effective variable in this research. 


\section{Political Performance: RPE}

This research will use political performance as a second independent variable with the potential to affect the distribution of income. As previously stated, some argue that political performance is a stronger economic determinant than is regime type.

Following the work of Kugler and Tammen (2012) this thesis will use RPE as a proxy for political performance. The aim of RPE is "to measure the marginal ability of governments to implement new options--controlling for commitments they previously made" (Kugler and Tammen 2012: 17). It captures the innate capacity of governments to implement the policies they choose--regardless of what those policies happen to be.

Because it is concerned with the realm of politics, the focus of RPE is on the extraction of resources from its population rather than natural resources or foreign aid. It is therefore measured through an analysis of tax revenue:

$$
R P E=\frac{\text { Actual } T a x}{\text { Predicted } T a x}
$$

A country's predicted tax takes into account the specific economic profile and tax structure of that country's economy. Because developed and developing countries differ greatly in how their economies are structured, there are two distinct models used to estimate RPE (Kugler and Tammen 2012):

Model 1 (Developing Societies):

$$
\begin{aligned}
\frac{T a x}{G D P}= & \alpha+\beta_{1}(\text { time })+\beta_{2}\left(\frac{\text { mining }}{G D P}\right)+\beta_{3}\left(\frac{\text { igriculture }}{G D P}\right)+\beta_{4}\left(\frac{E_{x p o r t s}}{G D P}\right) \\
& +\beta_{5}(\text { Crude Oil Production per Year })+\beta_{6}(O E C D)+\epsilon
\end{aligned}
$$




$$
\begin{gathered}
\text { Model 2 (Developed Societies): } \\
\begin{array}{c}
\frac{I \alpha x}{G D P}=\alpha+\beta_{1}(\text { time })+\beta_{2}\left(\frac{\text { minimg }}{G D P}\right)+\beta_{3}\left(\frac{\text { Exports }}{G D P}\right)+\beta_{4}(\text { Crude Oil Production }) \\
+\beta_{5}(G D P \text { per capita })+\beta_{6}(O E C D)+\epsilon
\end{array}
\end{gathered}
$$

For developing countries, agricultural production is used as a control variable because it captures the effects of a subsistence economy. In developed countries GDP more accurately reflects the tax base and therefore serves as an effective control variable in Model 2 (Kugler and Tammen 2012: 18). The allure of RPE is that it is a dynamic measure and independent of regime type. It allows for comparisons within a country over time as well as comparisons between different countries. Given that this study compares developing countries, data will be derived using Model 1.

\section{Corruption}

Corruption is another variable that will be examined in this research. A corrupt government should theoretically be less likely to enact policies that lead to broad development and more equal income distribution because it tends to squander resources or funnel them to small segments of the population. This thesis will utilize the Corruption Perception Index (CPI) developed by Transparency International, which is the most widely used indicator of corruption worldwide (Transparency International).

The CPI relies on a number of "data sources from independent institutions specializing in governance and business climate analysis" that "measure perceptions of 
corruption in the public sector" (transparency.org). Prior to 2012 it used that data to generate an annual score for each country ranging from zero to ten with zero being most corrupt and ten being least corrupt. However, in 2012 Transparency International altered its methodology, opting to score from 0 to 100, and making scores prior to 2012 incomparable to those after.

While the CPI may not be ideal for capturing the actual corruption apparent in a society, it has been validated as among the most effective measures of corruption available (Wilhelm 2002). However, one concern regarding the use of CPI in this research is that data only goes back to 1995 whereas this research is interested with the period from 1980 to the present. Nevertheless, a look at corruption and its relationship to functional distribution of income from 1995 to the present may provide valuable insight given the fact that corruption is theorized to negatively impact popular economic sectors (Wilhelm 2002).

\section{Development Strategy}

This research will also look at the specific development strategies that were pursued by the cases in question. Given the fact that the Third Wave of democratization corresponded temporally with the rise in popularity of the neoliberal development model-particularly in Latin America--it seems important to examine how the extent to which developing countries with new democracies pursued neoliberal reforms affected their functional income distributions and thus the shape of their development. 
In order to operationalize the development strategy pursued by the regimes being examined, this thesis will utilize the Structural Reform Index created by Eduardo Lora for the Inter-American Development Bank (IADB). "The structural reform index measures how favorable policies in the trade, financial, tax, privatization, and labor areas are for the proper working of markets" (Lora 2012: 3). The report in which this index was developed examines all Latin American countries annually from 1985 through 2012. It is scaled from zero to 1 with the highest scores corresponding with the most pro-market set of policies. Its only intent is "to measure the neutrality of the policies" (Lora 2012: 26). In other words, it does not measure the quality of economic policies, but rather, the extent to which they free markets.

The advantage of the IADB structural reform index is that it examines policy variables rather than outcome variables (Lora 2012). Unlike indices such as the Heritage Foundation Economic Freedom Index, which measure structural reforms and their effects on growth by examining variables such as inflation, foreign trade, or fiscal deficits, the IADB looks at the policies that affect these outcomes. In doing so, it better captures the magnitude of economic reforms (Kingstone 2011). Given the debate over the neoliberal economic strategy and the Washington Consensus it seems imperative to examine not only political capacity but the nature of the reforms implemented. As previously discussed, the Washington Consensus prioritizes inflation control and stability over unemployment, poverty, and economic equality. Radical analysis suggests that the neoliberal economic model benefits capital to the detriment of labor. As such, an inverse 
relationship between economic openness and labor's share of national income is expected.

This chapter has proposed a research design based on theory derived from the existing literature with the intent of examining how democracy and political performance affect economic development in two neighboring Latin American countries. The following chapter will look in depth into the political transitions of Argentina and Brazil through democratization in an attempt to ascertain how the quality of democracy affected functional income inequality in these two countries. Its goal is to tell a causal story regarding democratization and its effect on income inequality. 


\section{Chapter 4 Findings and Analysis}

The following chapter will examine the effects of democratization and political performance on functional income inequality in Argentina and Brazil. The goal of this chapter is to shed light on the interaction between the democratic process, political performance, corruption, and development strategies and policies. In doing so, it will attempt to answer whether an increase in the level of democracy or political performance contributes causally to an increase in labor's share of income in two underdeveloped countries that have historically suffered from relatively extreme poverty and inequality.

\section{The Authoritarian Periods}

Prior to 1984, both Argentina and Brazil were under authoritarian rule in the form of military dictatorships. Argentina was under military rule from 1966 to 1973 and again from 1976 through 1983. The second period was known as the "Proceso de Reorganizacion Nacional," and was welcomed by the people of Argentina and granted legitimacy in response to economic crisis and political violence that plagued the preceding civilian government. Eventually, it emerged as a brutal and violent regime that would ultimately crumble under the weight of its incoherence and an ill-advised military failure in the Falkland Islands in 1983. Across the border, Brazil's armed forces enacted a coup d'etat against the democratically elected government of Joao Goulart on March 31, 
1964, leading to twenty-one years of authoritarian dictatorship which ended with the democratic election of Jose Sarney on March 15, 1985.

\section{Level of Democracy}

During their respective periods of military rule, Polity IV scored Argentina a -9 on its scale from -10 to 10 placing it among the world's most complete autocracies. Argentina's Military Junta (JM) exercised complete authoritarian control of the political system and engaged in severe repression of civil society through an anti-subversion campaign known as the Dirty War, in which between 9,000 and 20,000 civilians were deemed "subversives" and were kidnapped, tortured, and often murdered. Repressive laws, justified by discretionary powers granted to the president in a state of siege, criminalized opinions, beliefs, and affinities. This gave the military commanders broad opportunity to use their authority in the context of anti-subversion (Arceneaux, 2001). The legacy of egregious human rights violations throughout the period would haunt the $\mathrm{JM}$ and play a major role in the eventual collapse, transition, and democratic consolidation.

In slight contrast to Argentina's JM, Brazil's authoritarian period began with a Polity IV score of -9 , but by 1975 it had improved to -4 and in 1982 its score increased to -3 (Figure 4.1). Brazil thus moved from "autocracy" to "anocracy" according to the Polity Project's coding. Thus, while Brazil and Argentina were both governed by an autocratic regime, Brazil's dictatorship was comparatively less repressive. This signifies 
two differences between Argentina and Brazil: Brazil's transition to democracy occurred two years later than Argentina's and it transitioned from a less authoritarian regime than that of Argentina.

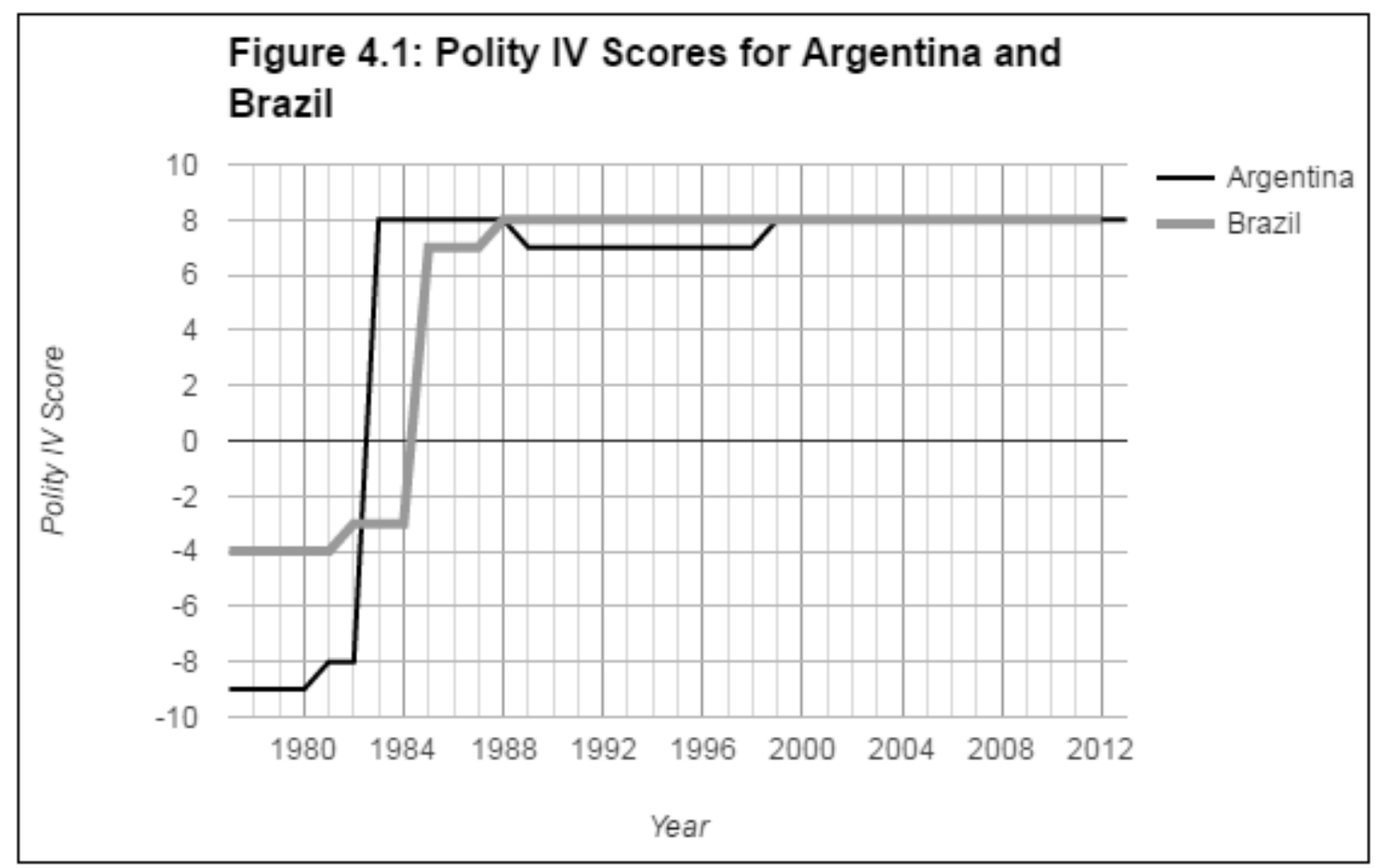

\section{Political Performance}

For reasons previously stated, Relative Political Extraction (RPE) will serve as the proxy for political performance in this analysis. From the time that the JM took power of Argentina in 1976 to the time of regime collapse in 1983, Argentina's RPE dipped from 1.073 to 0.626 , a decline of roughly 42 percent (Figure 4.2 ). This is indicative of the stark deterioration of the JMs ability to govern effectively. Similarly, Brazil's military 
government appeared to be losing political capacity at a rapid rate through its last decade of rule. From 1977 to 1985 , Brazil's RPE score dropped from 1.36 to 0.89 (Figure 4.3). It is clear from this data that the political capacity of both dictatorships rapidly deteriorated in the years leading up to their collapse. A regime that fails to perform is likely to lose power whether in the context of democracy or autocracy.

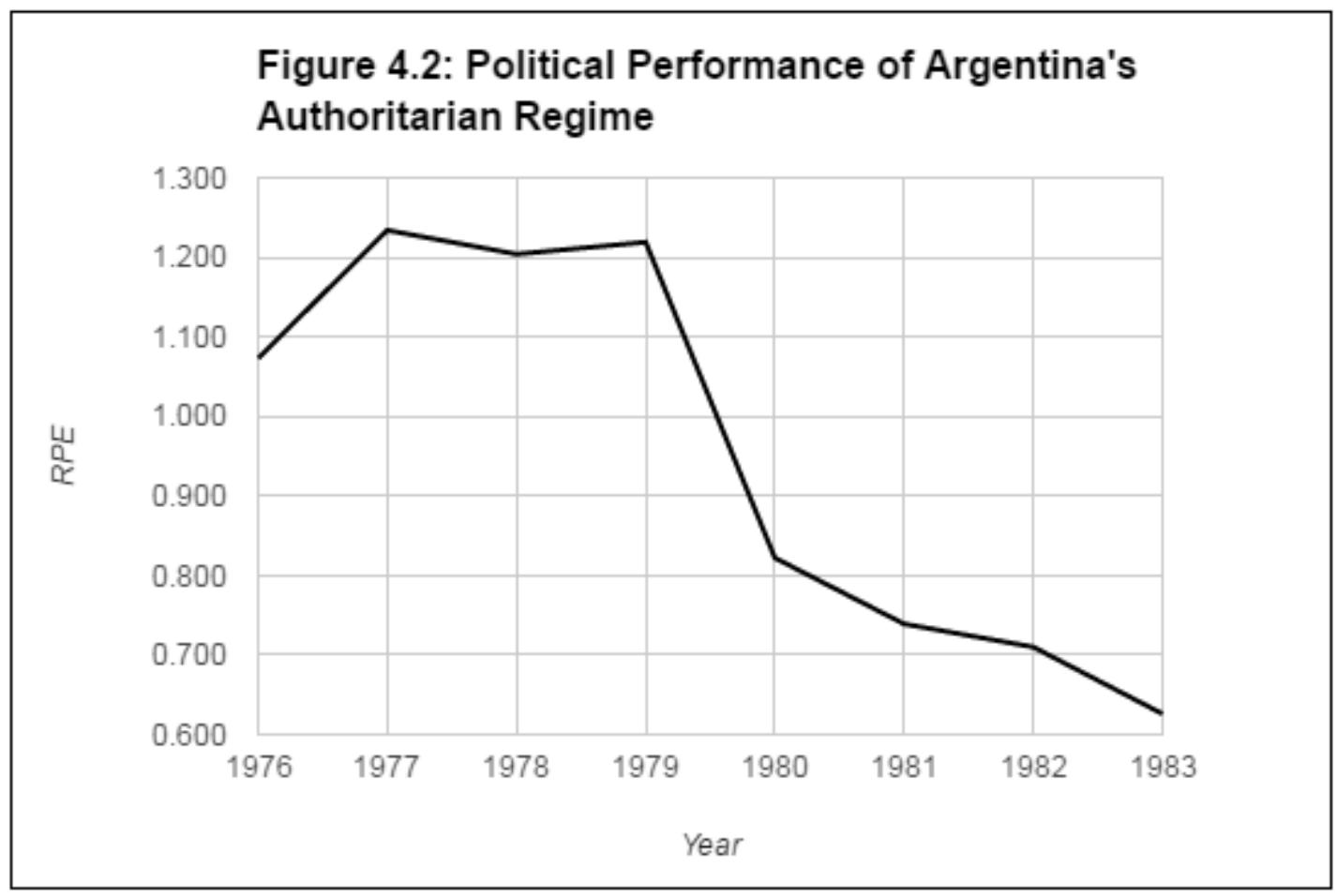




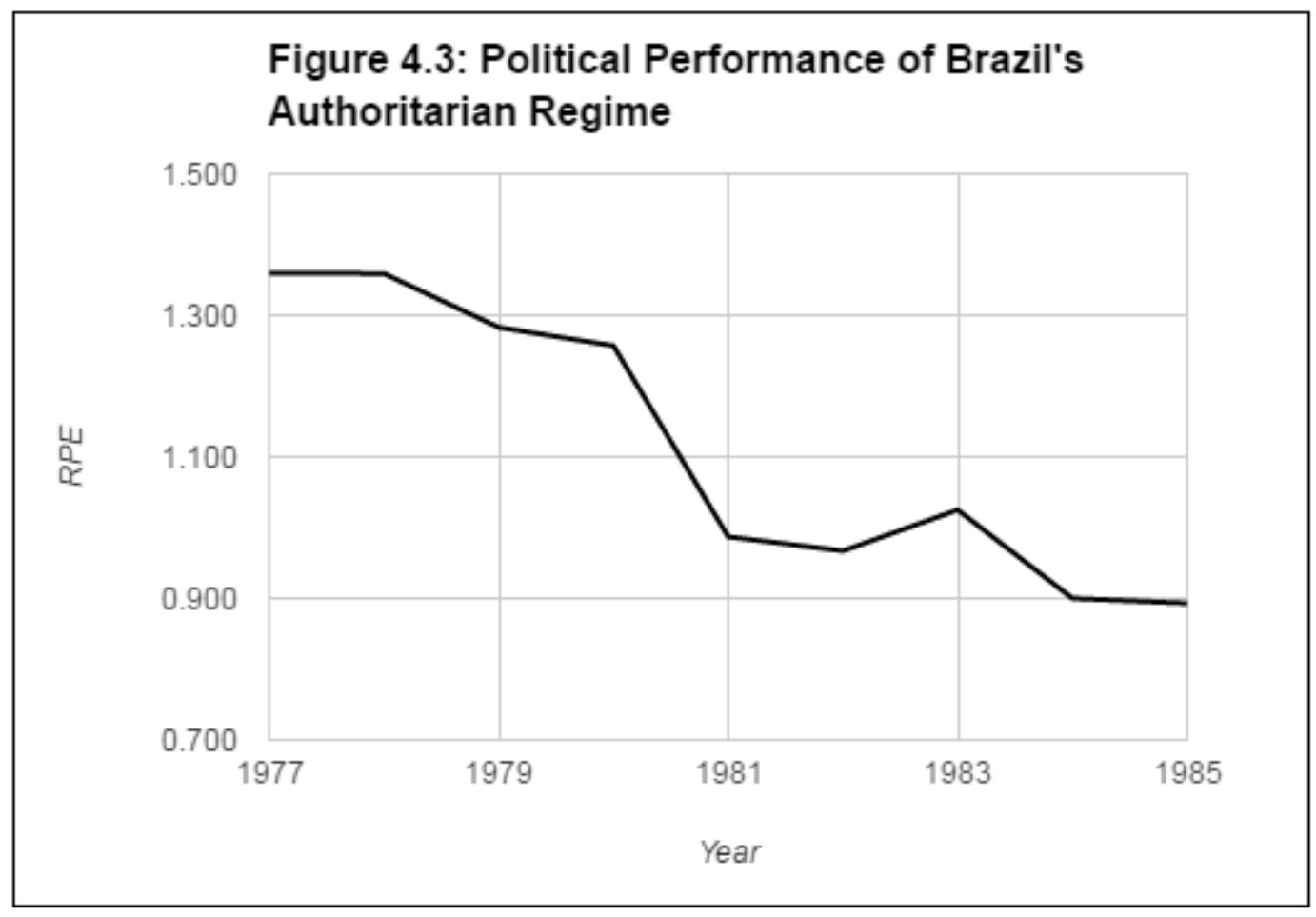

\section{Corruption}

Unfortunately, the Corruption Perception Index (CPI) does not extend back to the time of these two military dictatorships. However, there is evidence to suggest ample corruption. For example, members of the Argentine military benefitted economically from their position in the regime. During this period salaries for government positions were doubled through budget increases and outright corruption. These increases in administrative spending can be seen as patronage, a form of clientelism (Remmer 2007). Additionally, there was substantial "war booty" involved with the dirty war against subversion. These phenomena coupled with the sharp decrease in political capacity in 
each regime suggest weak and corrupt states and therefore predicts a dearth of broad and equitable economic development.

\section{Development Strategy}

The development strategies implemented by the authoritarian regimes of Argentina and Brazil differed significantly from one another. The JM in Argentina took power following the death of Juan Peron, who oversaw a period which can be seen as an extreme example of corporatism and populism following the model of ImportSubstitution Industrialization (ISI). When the JM took power, Argentina was facing economic crisis and extreme inflation as well as violent political reprisal. The JM, like much of the region at the time, saw neoliberalism as the remedy to the failures of ISI. They turned to conservative Minister of the Economy Jose Alfredo Martinez de Hoz, who prescribed "a hefty dose of the free market" (Arceneaux, 2001: 130). However, the JM was unable to implement a cohesive set of reforms due to its institutional makeup. As a result, the reforms that were enacted were done so piecemeal, in a disjointed fashion, and hurt nearly every sector of the economy. The neoliberal overhaul would end up failing miserably.

Compared to the JM, the authoritarian period in Brazil corresponded with a closed economy guided by “a dictatorship of ultra-nationalistic businessmen” (Pang 2002: 132). Brazil's authoritarian regime continued with the ISI strategy throughout their reign, 
which involved privileging the durable goods sector and included export subsidies, import restrictions, and currency devaluations (Feijo and Nassif, 2013). This was in contrast with the Asian Tiger countries, which pursued an export-oriented development strategy with significantly more success than Brazil. By 1985, Brazil’s IADB structural reform index score was 0.3 . At the time of Brazil's transition to democracy, its economy was significantly more closed and state-guided than that of Argentina, as shown by the fact that the IADB structural reform index scores for Argentina and Brazil were more distant from each other than at any point in time since (Figure 4.4).

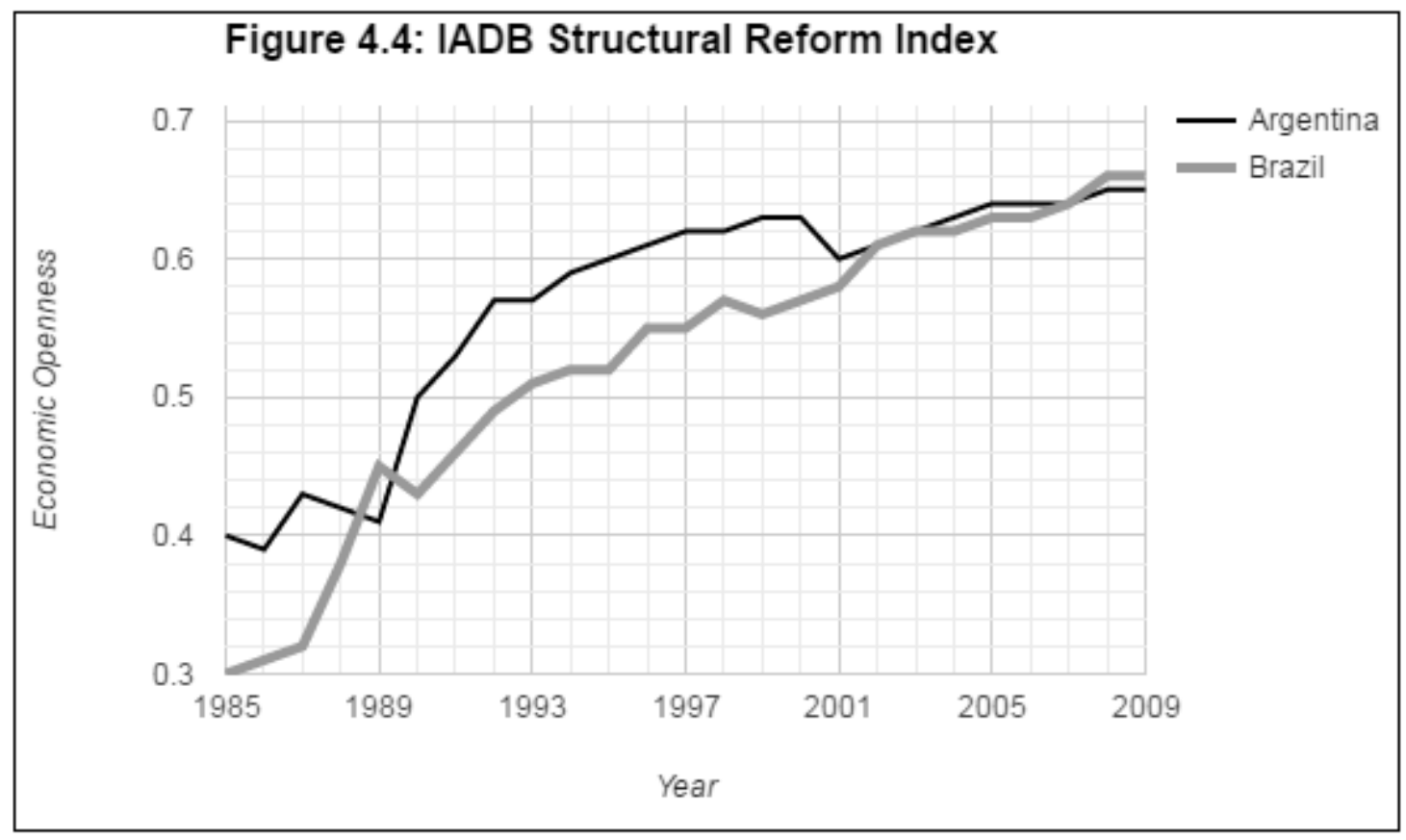




\section{Income Distribution}

How did these factors affect income distribution? While the data regarding employment and wages for this era is largely incomplete and inaccurate, the literature suggests differing income distributions for Argentina and Brazil. Argentina had a distorted, inept tax system that penalized the agriculture industry and therefore is likely to have contributed to economic inequality during the JM's reign given that agriculture employed a relatively large segment of the workforce (Corrales 2002: 63). On the other hand, the literature on Brazil suggests a relatively equitable income distribution. The authoritarian period was one in which Brazil "witnessed an extended period of social mobility, with most individuals moving upwards in relation to their fathers during the 1950-1980 era" (Wogart 2010: 386). However, any upward mobility witnessed during this era came in the context of unsustainable economic growth resulting from the ISI development strategy it pursued. That said, if the literature is to be taken as accurate, the JM oversaw a relatively more unequal functional income distribution than Brazil's authoritarian regime.

\section{The Transition to Democracy}

By 1983 the military dictatorship of Argentina crumbled under the weight of its own disjointedness and incompetence in the face of economic crisis and agreed to give 
way to democratically elected leadership. Raul Alfonsin, a non-Peronist from the Radical Civic Union (UCR) party, won Argentina's presidential election. Two years later in Brazil, under a great deal of public pressure and popular protest, the military government decided to reinstall direct presidential elections. Tancredo Neves of the Brazilian Democratic Movement Party (PMDB) won the election, but became severely ill before assuming office, eventually passing away on April 21, 1985. His ticket-mate, Jose Sarney, assumed office as Brazil's first civilian president since 1964. Thus began the transition to democracy in the two largest economies of South America.

\section{Level of Democracy}

The transition to democracy from 1983 to 1984 earned Argentina a shift on the Polity IV index from -8 to +8 , placing it in the range of "democracy." The transition went relatively cleanly and Alfonsin, who ran on a platform of human rights in the wake of the Dirty War, faced virtually no threat from the military and successfully purged the new government of members of the JM. Alfonsin's tenure as president of the renewed democracy did not continue smoothly, however. From 1988 to 1989, Argentina's Polity IV score slid one unit to +7 . This would be the lowest that Argentina would ever dip again. Perhaps due to the new and fragile democracy, or perhaps for his inability to work effectively with policymakers, Alfonsin was unable to curtail the economic crisis inherited from the JM regime. In mid-1989, amid the most severe hyperinflation the 
country had ever seen, and in the face of looting and violence leading to 3201 arrests and 16 killed, Alfonsin resigned early in what has been called a "market coup" (Corrales 2002: 86). Early resignation of an executive does not bode well for a newly formed democracy, but the revolving door of the executive office would remain a theme in Argentine politics for decades.

Brazil's transition also earned it an immediate increase in its Polity IV index score from -3 to +7 . This placed Brazil in the category of "democracy" for the first time since it briefly passed the threshold in 1947. By the end of Sarney's term in office, Brazil's Polity IV score reached +8 , where it has remained since (Figure 4.1). The greatest contribution made to democracy during Sarney's term was the 1988 Constitution. "Under pressure from social movements, delegates to the constitutional assembly of 1987-88 enshrined in the new charter a wide array of social rights that reflected a broad understanding of citizenship. These included rights to housing, healthcare, employment, and education" (Hunter and Sugiyama, 2009: 33). However, the infrastructure that would be needed to implement these broad guarantees had not yet been put in place. How to administer these rights to housing, healthcare, employment, and education was to be decided by the constitutional assembly. "In this forum, democratic dynamics thus had a double-edged effect: to extend coverage to the extremely poor while enhancing the benefits of the better-off, who lobbied to keep their privileges" (Hunter and Sugiyama, 2009: 35). With regard to the distribution of resources, it appears that democratization would not 
automatically lead to the anticipated impact. The privileged groups would retain their relative privilege.

\section{Political Performance}

Both Argentina and Brazil enjoyed an increase in political performance accompanying their transitions away from authoritarianism. By 1989 Argentina's RPE rose to 0.840 (Figure 4.5). This is a 34 percent increase from 1983, the last year of military rule. In Brazil, Sarney's regime saw an increase in RPE from 0.90 to 1.09 in just one term, though its trajectory fluctuated sharply (Figure 4.6). This is perhaps due to the growing pains of the new republic. Nevertheless, both countries' transitional regimes oversaw an increase in political capacity, making it clear that they governed more effectively than their authoritarian predecessors. 

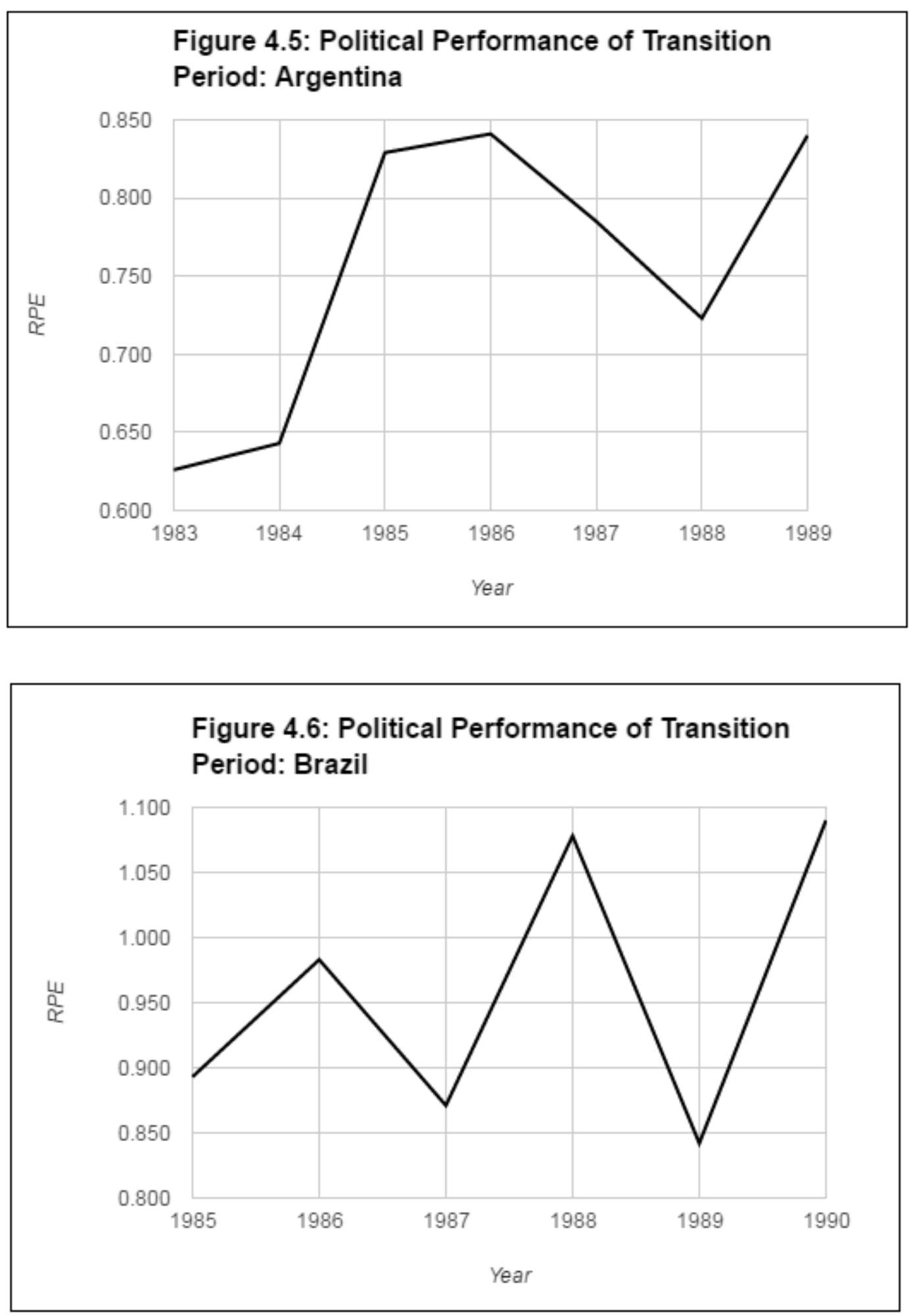
Development Strategy

As previously stated, the authoritarian regime of Argentina oversaw a far more open economy than that of Brazil. Argentina's transitional period saw no discernable trend regarding its Inter-American Development Bank Structural Reform Index (SRI) score, whereas Brazil's transitional government, led by Jose Sarney, took the country from one of the most closed economies in the region (Pang 2002) toward a more open economic development strategy. By the end of their first democratic regimes, Argentina and Brazil converged around the same level of economic openness (Figure 4.7).

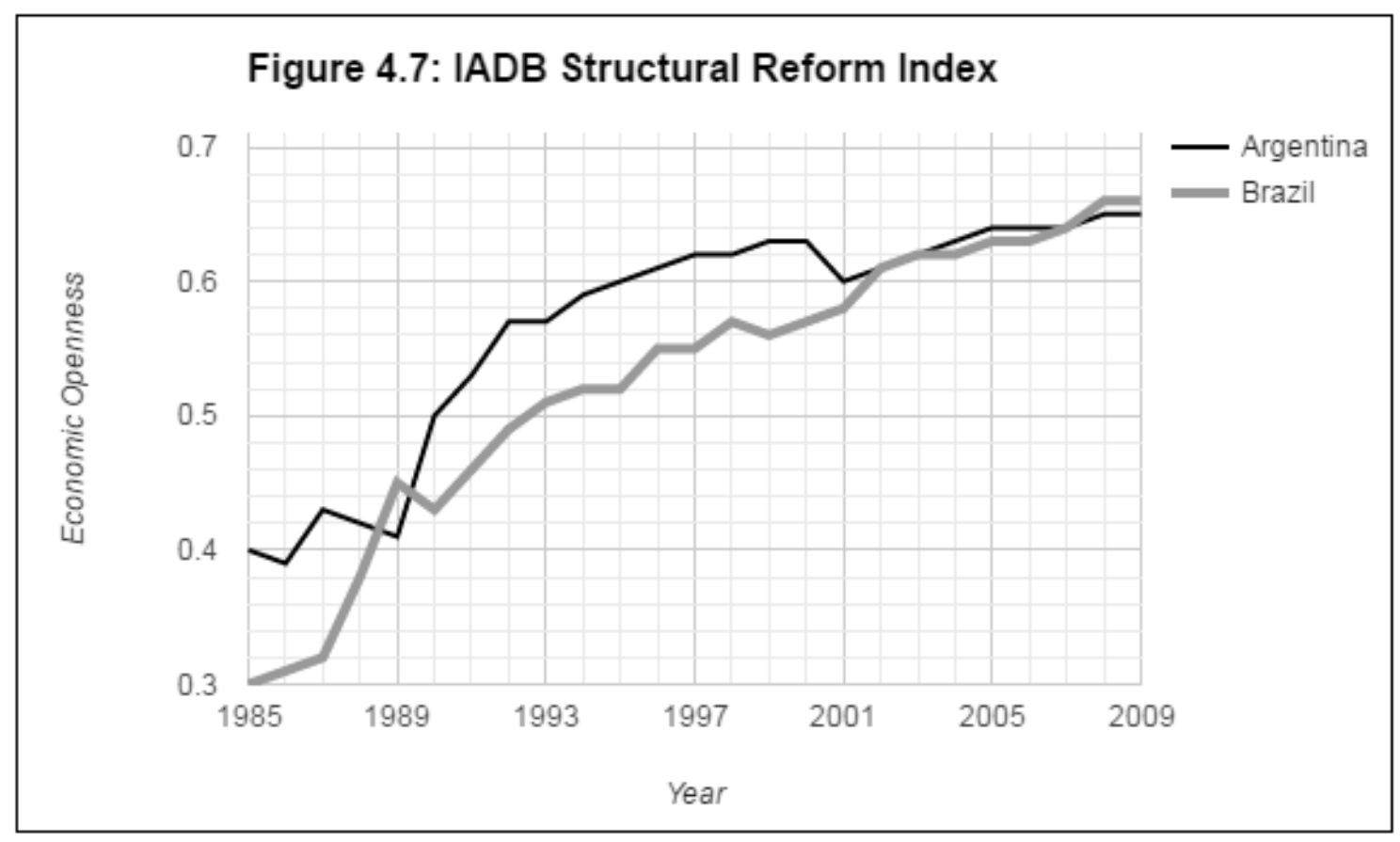


It is important to note that both Argentina and Brazil faced economic crises during their transition periods. While Argentina did not move to open its economy in this period, Alfonsin did attempt some major reforms, as did Sarney in Brazil. In order to attack the economic crisis, Alfonsin unveiled the 1986 Austral plan, which involved freezing prices and replacing the Argentine peso with the Argentine Austral at 1,000 to 1 . It was initially successful at curtailing inflation but by 1988 the economy fell back into recession. That spring, the regime unveiled the Primavera Plan, a stabilization plan based on dual exchange rates and an implicit tax on exports Conde 2009: 86). It again had initial success at curbing inflation, but Alfonsin failed to consolidate the reforms and the economy again spiraled out of control, leading to a landslide victory for the PJ's Carlos Menem in the 1989 elections, to whom Alfonsin would secede the office of President several months before the end of his term. In Brazil, Sarney's most significant policy package was an attempt to curb the dramatic inflation his country endured: The Cruzado Plan. The Plan was based largely on freezing prices, wages, and exchange rates. It failed. Sarney left office in 1990 with inflation at 80 percent per month, a deficit of 5-7 percent of GDP, and external and internal debt totaling greater than $\$ 200$ billion USD (Pang 
2002). In both Argentina and Brazil, the transitional regimes failed in their attempts to curtail hyperinflation and economic crisis.

Income Distribution

While there is not sufficient data to examine a change in labor's share of national income for Argentina and Brazil during the first democratic regimes, there is evidence to suggest that the lower economic sectors were hit particularly hard by the economic turbulence of this period. The literature suggests a major shift in labor's share of income throughout the 1980s as well as a significant increase in poverty (Hunter and Sugiyama 2009). Between 1980 and 1989, poverty tripled in Argentina (Corrales 2002: 89). “The transfer of national income to the workers [in Argentina] shrank from 50 percent in the early 80 s to 28 percent of the GDP by 1989" (Pang 2001: 97). When coupled with the fact that hyperinflation disproportionately hurts those worse off economically, it becomes apparent that both Sarney's and Alfonsin's terms involved increased economic inequality. 


\section{The Consolidation Period}

In 1989 and 1990 Argentina and Brazil saw an end to the reign of their respective transitional presidents. In Argentina, Alfonsin's failed attempts at economic stabilization in the face of hyperinflation and political backlash harmed him greatly in his bid for a second term. What resulted was a landslide victory in the 1989 election for Carlos Menem and the Judicialist Party (PJ). The crisis got so bad that Alfonsin was compelled to leave office several months early. It is in this context that Menem and Peronist PJ regime took power. In Brazil, Fernando Collor de Mello of the conservative National Reconstruction Party (PRN), defeated Luiz Inacio Lula da Silva of the Workers' Party (PT) to become the first president elected directly by the people in 29 years, but failed to complete his term in the face of corruption and impeachment hearings. After his vice president, Itamar Franco, completed the final two years of Collor's term, he handed the baton to Fernando Henrique Cardoso, who would control the executive office for two terms, paralleling the two-term presidency of Menem in Argentina.

\section{Level of Democracy}

By 1989, Brazil's Polity IV index score was already at +8 whereas Argentina would reach +8 during the second half of Carlos Menem's second term (Figure 4.1). Nevertheless, both Argentina and Brazil were classified as democracies by the start of this period, and by the end of this period both had identical Polity IV index scores. 
Democracy did not backslide significantly during this period, but it also failed to make significant gains. The Latin American trend of hyperpresidentialism remained an issue. In Brazil, Collor frequently used "temporary measures" to circumvent Congress (Polity Project). The hyperpresidentialism of Menem, however, is more contested. One of the main points of contestation with regard to Menem's regime involves the democratic nature of his economic policy reforms. As will be shown shortly, Menem oversaw an extreme opening of the Argentine economy and strong adherence to the neoliberal development model. Some argue that such reforms, which are usually unpopular because they tend to involve cuts to social spending and increases in short and midterm unemployment, are difficult to pass through democratic channels due to the ability of constituencies to sanction politicians through the vote. In democracies such as the one Menem inherited, they argue, neoliberal reforms must occur "by surprise" (Pereira, Maravall, and Przeworski 1993: 9). Indeed Menem ran on quite a different platform from that on which he governed. However, it is argued that because of democratic pressures, Menem's reform packages necessarily required a shift in popular preferences (Armijo and Faucher 2002). Eul-Soo Pang (2001) argues that, relative to other economic reforms in the region, Menem's reforms went through democratic channels. 'Unlike Mexico, all of these changes in Argentina were effected through legislative processes, not by executive fiat" (Pang 2001: 111). It is unclear, however, how accurate this viewpoint is. The shift in public opinion to which Armijo and Foucher (2002) refer was fleeting at best. "Public opinion polls showed that support for 'the government's economic policies' 
among those who voted for the $\mathrm{PJ}$ in 1989 declined sharply, from 70 percent in September 1989 (shortly after announcing the reforms) to 27.9 percent in June 1991" (Corrales 2002: 131). Also, the characterization of Menem using democratic channels may be misleading. By the end of his reign, Menem had issued 178 Decrees by Necessity and Urgency (DNU), mostly in economics. This is in contrast to twenty such decrees issued between 1853 and 1989 (Corrales 2002: 134).

There were other hindrances to Argentine democracy during the Menem era. Internal political disputes led to general policy incoherence, particularly in his first term. Throughout the 1990s Argentina was plagued by partisan politics and internal fiscal fighting that seemed to bankrupt government (Corrales 2002). Menem's dominance of Argentine politics, which included not only the aforementioned decrees but the packing of the Supreme Court with political supporters and changing the constitution to allow for a second term is seen as a strike against executive constraints (The Polity Project).

On the other hand, parts of Menem's regime shine a positive light on the quality of its democracy. Argentina was the only country in Latin America that participated in the first Gulf War, linking it to global democracy. Unlike Kuwait and Saudi Arabia, which border Iraq and therefore had imminent security interest in the conflict, Saddam's Iraq posed no threat to Argentina. Its participation can therefore be explained at least in part by a desire to align with western, democratic powers. There are also signs that the regime was responsive to public pressure, which is to be expected from a functioning democracy. For example, in the fall of 1995, with unemployment reaching 17 percent, 
Menem responded to public pressure to ease the tight money supply and curb unemployment by removing his finance minister Domingo Cavallo, the architect of Menem's economic strategy. Also, the Convertibility Law of 1991, which pegged the Austral to the USD, is an example of economic legislation which passed through democratic channels and led to sustainable reform (Corrales 2002).

While Brazil did not backslide to authoritarianism, there are indeed concerns over the quality of Brazilian democracy during this period. In 1992, Congress removed Collor from power in the face of rampant corruption. Collor resigned in the final months of 1992 in an attempt to thwart impeachment hearings. In accordance with constitutional procedures regarding impeachment hearings, his vice president, Itamar Franco, became acting president. Collor officially resigned on December 29, formally leaving Franco to serve the remaining two years of Collor's term. The ability of Congress to check the power of the executive branch can perhaps be seen as a positive indicator of democratic consolidation, but the inability of Brazil's first directly elected president to serve a complete term indicates democratic weakness.

After the two year Franco presidency, which involved relative success at curbing hyperinflation, his Finance Minister--Cardoso--won a landslide victory and served as president for two terms until 2002. While Brazil's Polity IV score remained at +8 throughout Cardoso's two terms, the literature suggests Brazil's democracy was not initially functioning well for him. "Months into office, Cardoso was unable to push his reforms through congress. Politics since Sarney had degenerated into 'what's in it for 
me,' and unless the president reciprocated pork for vote it became impossible to get a bill approved in congress" (Pang 2002: 143). Corruption in the form of clientelism had tainted the lawmaking process.

Cardoso would prove unable to eradicate the legacy of bartering favors between the executive and legislative branch, but he was successful in forging popular support and a broad consensus to accept the generally unpopular necessities of "paying taxes, trimming fiscal fat, restraining excessive wage demands by powerful unions, and convincing congress to think boldly" (Pang 2002: 143). His ability to forge such support earned him a second term, which could be argued as popular support for a significant liberalization of Brazil's economy. Some argue that this political maneuvering allowed Brazil to reap the benefits of the neoliberal development model despite their lack of popularity and at the same time strengthen democracy. "The limited engagement in neoliberalism allowed the positive impact of globalization to seep into the country, while Cardoso consolidated political democracy, endorsed press freedom, and improved on human rights" (Pang 2002: 144). From this perspective, Cardoso used neoliberalism and political savvy to benefit both democracy and development. However, a public opinion poll showed a decrease in respondents who said that "democracy was preferable," from 50 percent in 1996 to 43 percent in 2007 (Hunter and Sugiyama, 2009: 31). One explanation is that neoliberal economic reforms increase economic inequalities, which heighten feelings of unfairness and inefficacy and diminish the perceived legitimacy of a country's political institutions. Another explanation is that public ignorance weakened 
democracy and made reform difficult. For example, a 1995 survey showed that a majority Brazilians thought they would be harmed by Cardoso's antipoverty entitlement reform proposals (Hunter and Sugiyama 2009). A lack of public understanding may have led to resistance that slowed reform and had democracy working against the public interest.

\section{Political Performance}

The 1990s were a period in which Argentina and Brazil diverged regarding the trajectory of their political capacity. Argentina's RPE was 0.840 when Menem took office in mid-1989. It peaked at 1.201 in 1992 before taking a massive dive and bottoming out at 0.644 in 1995 . Menem finished his second term with an RPE of 0.729, a 13 percent decrease from the beginning of his reign and 29 percent lower than his peak in 1992 (Figure 4.8). What was responsible for the collapse of Menem's political capacity in 1992? It appears that corruption played a significant role. 


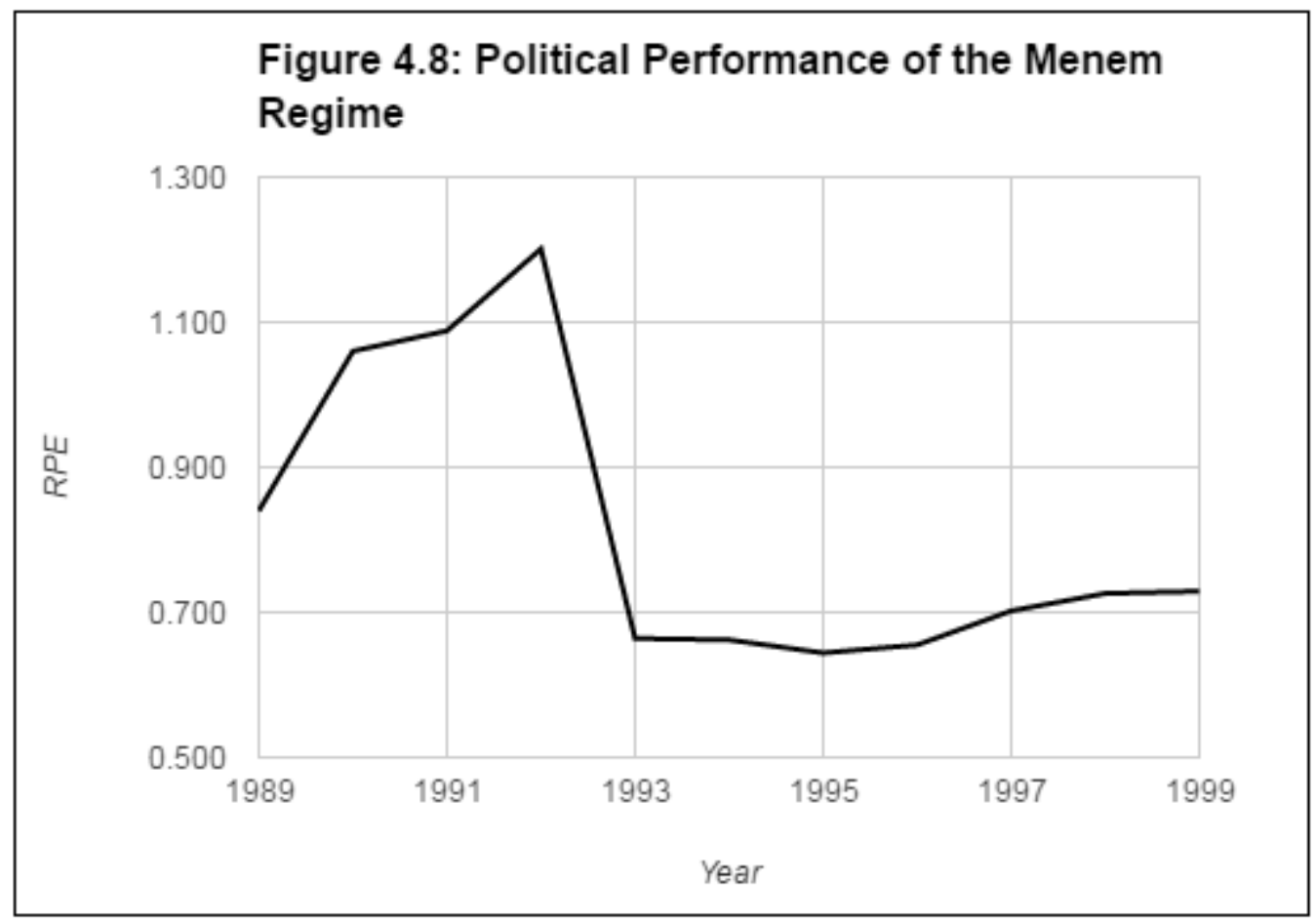

Unlike Argentina, Brazil's political capacity showed a net improvement during this period. However, this improvement was inconsistent and varied with each of the three executives in office. Collor's abbreviated term corresponds with a decrease in political performance. From 1990 to 1993, Brazil's RPE score decreased from 1.09 to 0.84. However, the shortness of Collor's term in office renders it difficult to determine the extent to which Collor's governance is responsible for the loss of political capacity. Nevertheless, a pattern has emerged in which a plummet in RPE score tends to precede an abrupt regime change. ${ }^{4}$ Given that Franco merely served the remaining term of his impeached president, it tempting to treat 1993-1995 as a continuation of the Collor

${ }^{4}$ From 1980 to 2011 , Brazil's RPE had a mean of 1.12 and a standard deviation of 0.20 . The decrease in RPE from 1990 to 1993 is therefore greater than one standard deviation. 
regime. Nevertheless, Brazil experienced a rebound in political performance after Collor's resignation. From 1993 to 1995, Brazil's RPE increased from 0.84 in 1992 to 1.06 by 1994, before dipping slightly (Figure 4.9 ).

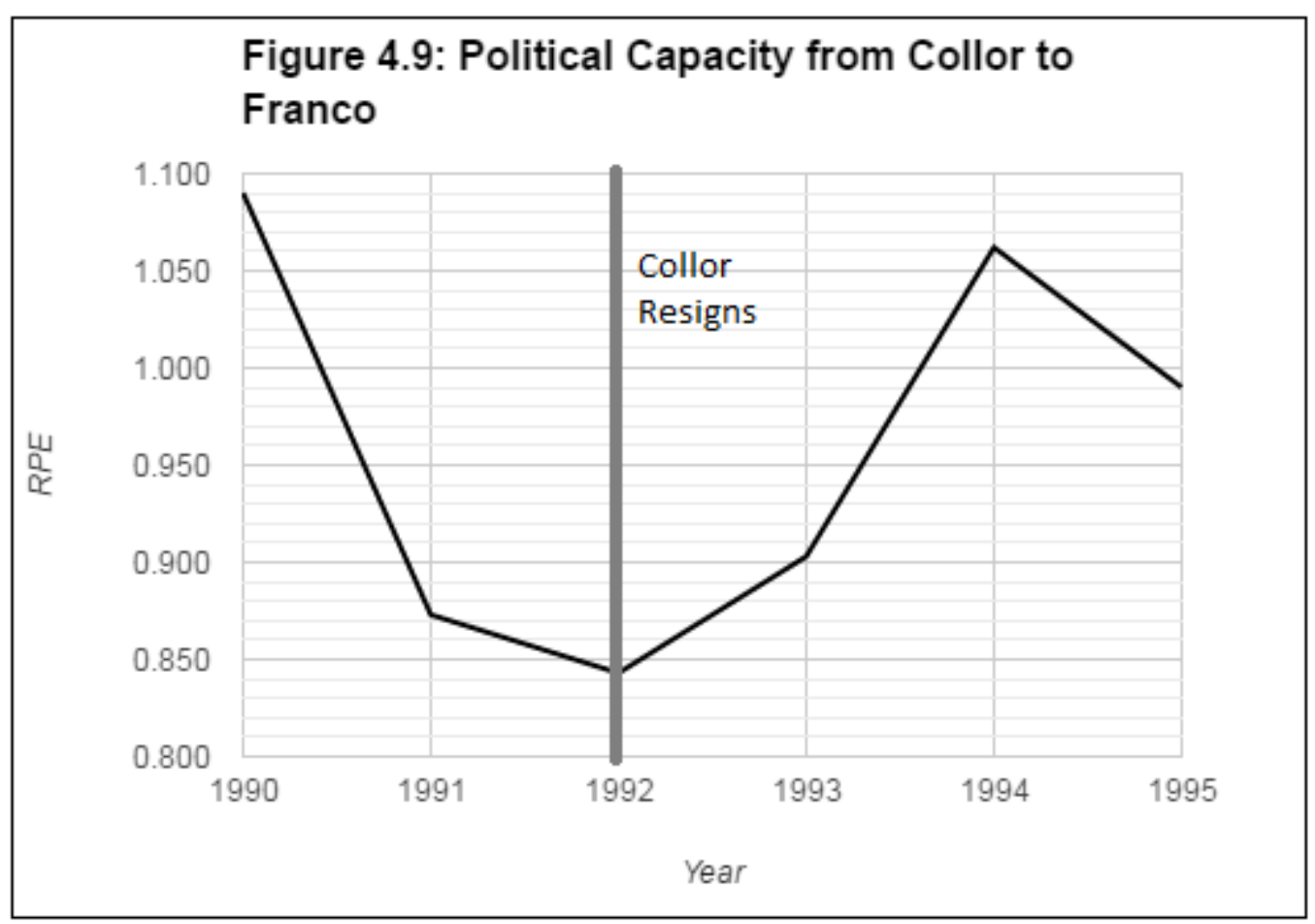




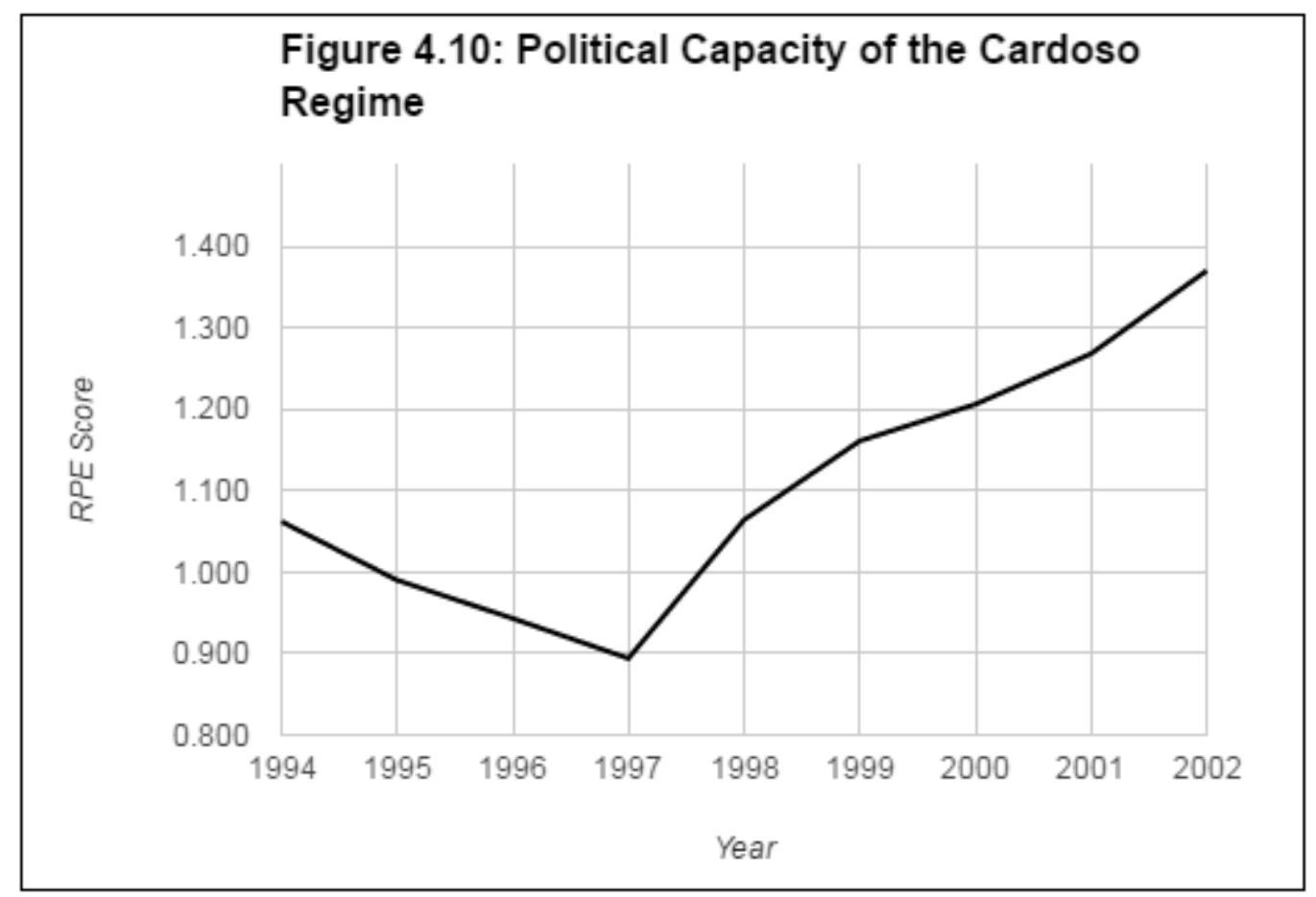

It was Cardoso's two terms in office which would eventually yield the net increase in Brazil's political performance during this period. Brazil's RPE score dropped from 1.062 to 0.894 from 1994 to 1997 , before rising sharply through the end of his term. Cardoso left office with a RPE score of 1.370 in 2002, bringing Brazil above the global average (Figure 4.10). This significant improvement in political capacity of the two-term Brazilian president is in stark contrast with the drop in political performance during the two-term reign of Menem in Argentina. It appears that corruption is at least a partial explanation for this difference in the quality of governance between the two regimes during this consolidation period. 


\section{Corruption}

Corruption is a political legacy throughout Latin America, and Argentina and Brazil are no exception to this phenomenon. This consolidation period, however, is one in which the perception of corruption and change therein differed between the two countries. Argentine politics had the reputation of corrupt officials, both military and civilian prior to Menem's reign, but his regime perhaps suffered more from corruption than any other in the post-JM republic. Argentina's CPI score went from 5.2 in 1995 to 3.5 in 2000 (Figure 4.11). While there is no CPI data corresponding with Menem's first term, this still suggests a drastic rise in corruption in the Menem era.

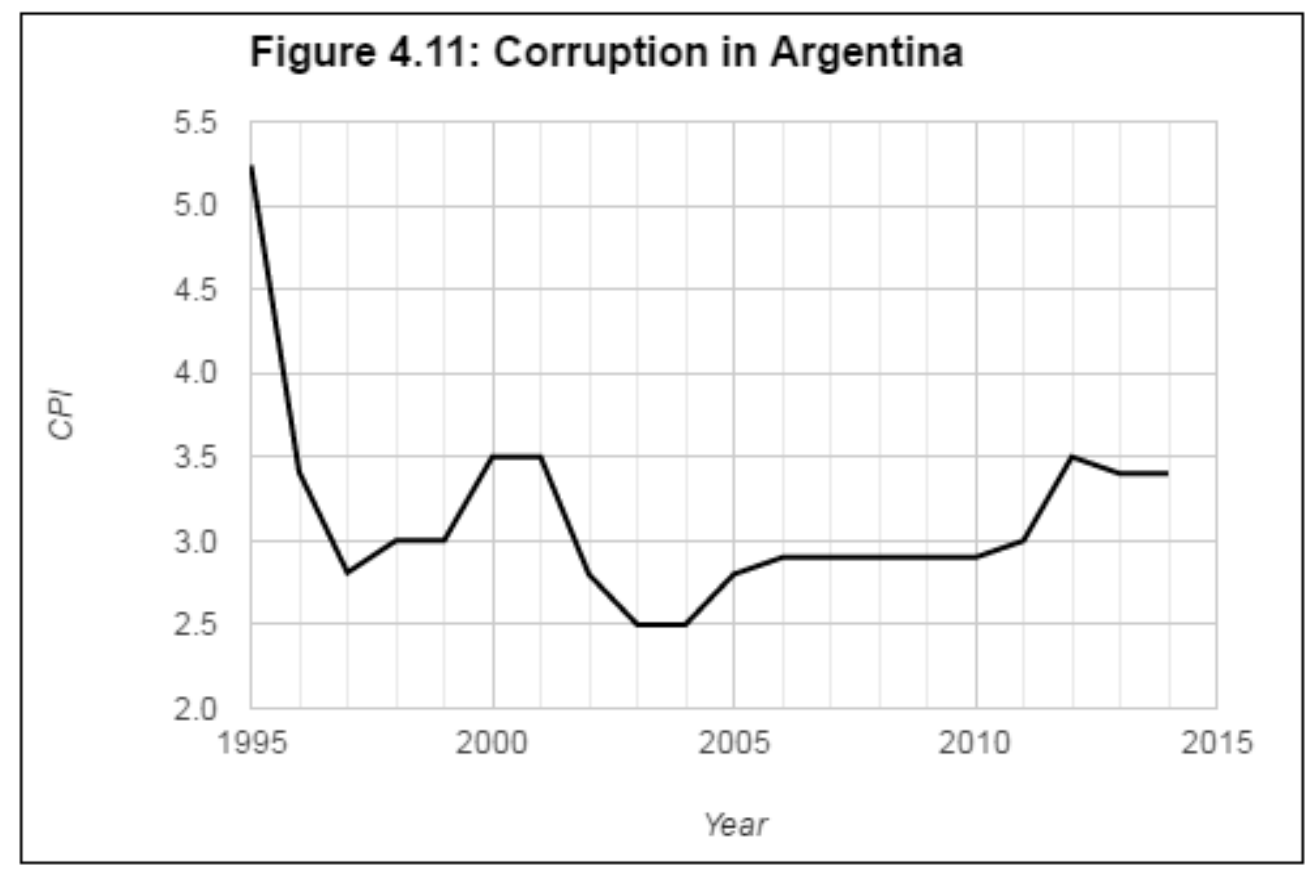

There is also qualitative evidence within the literature to suggest that corruption was endemic to Menem's first term. In 1990 "corruption in the highest places threatened 
to unravel the reforms" that Menem had begun in the previous year. "Menem's men and women simply took advantage of the situation and indulged overtly in excessive personal enrichment" (Pang 2001: 101). In order to retain the support of the Peronist party members and followers, Menem doled out subsidies--patronage in the purest sense. There was also a 1990 event in which President Bush visited Buenos Aires in order to address complaints of elite US firms that "corruption, bureaucratic inertia, and outright demands for bribes" had rendered them unable for them to do business in Argentina (Pang 2001: 104). The companies that filed such complaints were Enron, Firestone, Goodyear, Bell Atlantic, and AIG.

There is a possible connection between corruption and the economic liberalization to be discussed next. "The Argentine corruption was the appropriation of the state power to maximize personal economic gains by Menem's advisers and followers. Deregulation and privatization created unprecedented opportunities for holders of state power to abuse" (Pang 2001: 104). The opening of the economy, which included selling off massive state-owned firms, created opportunities for government officials and their business allies to use their position for personal profit. Evidence suggests that this form of corruption was rampant throughout the Menem regime.

While Argentina's story is one of increased and rampant corruption throughout the Menem regime, Brazil's corruption story of this period is somewhat different. As his eventual impeachment hearing suggests, corruption was a problem for the Collor regime. In short, it sapped his political capital, rendering coherent governance all but impossible. 
While there is no CPI data for the Collor regime, there is ample literature documenting the corruption in Brazilian politics during his abbreviated term (Flynn 1993; Panizza 2000). The most prominent instance involves Collor's campaign treasurer, Paolo Cesar Farias. Collor enjoyed the best financed campaign in Brazilian history. After the election, Collor put three of his brothers in "strategic places for money making." "The name of the game was to garner federal funds for public works projects and economic developments projects for specific individuals and companies." The result was a "facilitator, greaser, and influence-peddling company" (Pang 2002: 138). Farias was convicted and sentenced to seven years in prison. Collor's role in the affair led to his eventual impeachment hearings and early abandonment of the presidential office.

Franco thus inherited office due largely to the corruption of his predecessor. Therefore, while CPI data is unavailable prior to 1995, Brazil's perceived level of public corruption must have been relatively high. The trajectory of Brazil's CPI in the wake of Franco's term suggests that corruption declined during his two years as acting president. This decline appeared to continue throughout the two Cardoso terms that followed. Brazil's CPI score improved from 2.7 to 3.9 over that time, though it did backslide in Cardoso's second term (Figure 4.12). As previously mentioned, politics had disintegrated into favor-swapping clientelism between the executive and legislative branch by the time Cardoso had entered office. While Cardoso failed to eradicate the swapping of favors, the data clearly suggests that corruption was improved upon during his two terms. 


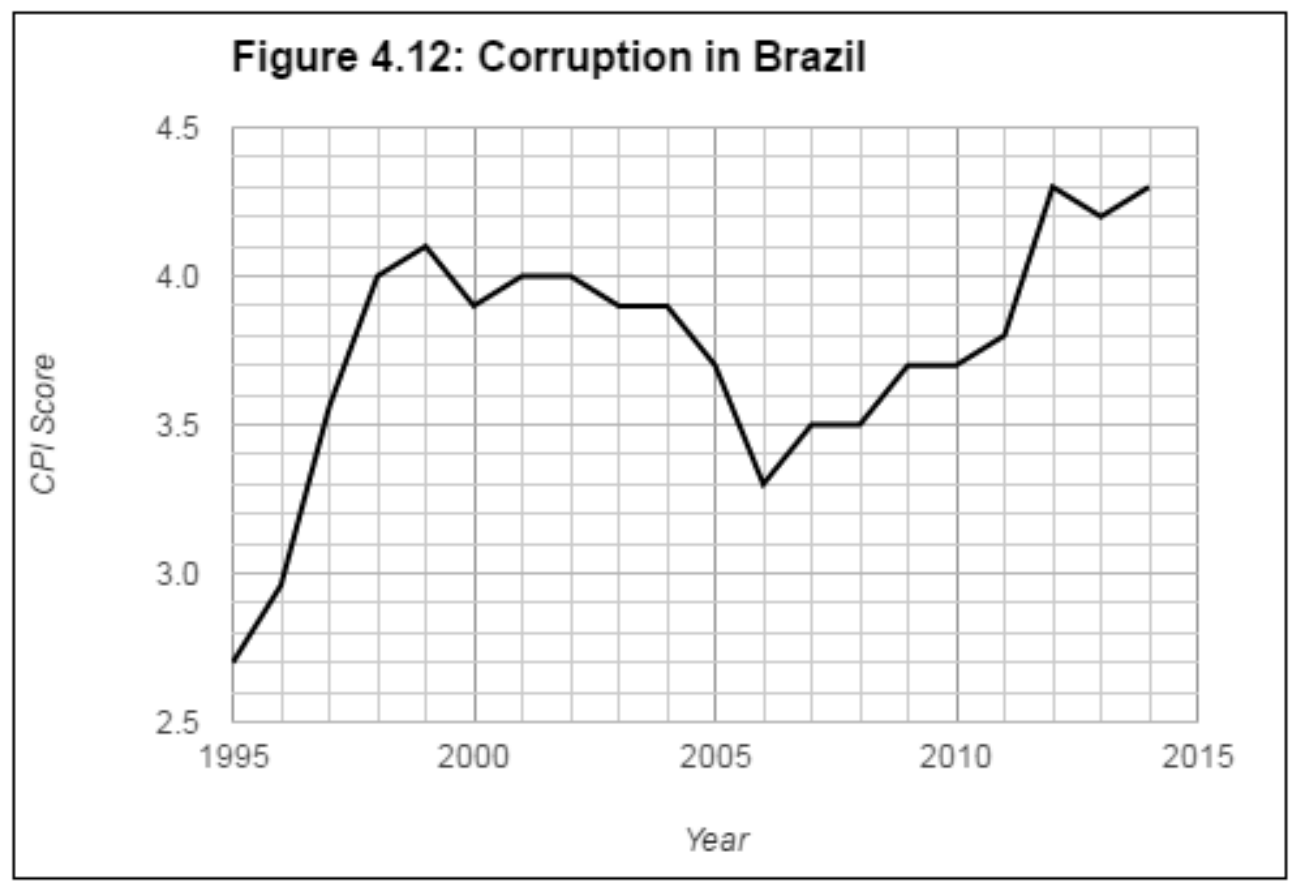

\section{Development Strategy}

This period in both Argentina and Brazil was characterized by a significant shift toward the neoliberal economic development model. While the Argentine economy was slightly more closed than Brazil's in 1989, by 2000, both countries had opened their economies significantly.

In Argentina, despite running on a Peronist, populist platform, Menem undeniably undertook a dramatic liberalization of the Argentine economy. Argentina's IADB Structural Reform Index score rose from 0.41 in 1989 to 0.5 in 1990 . By the end of Menem's reign in 2000, Argentina scored a 0.63 (Figure 4.13). In Brazil, Collor's 
presidency coincided with a continued liberalization of Brazil's economy. Brazil's IADB structural reform index score increased from 0.43 to 0.51 in just three years. Franco saw Brazil's score increase slightly to 0.52 while completing Collor's term, and Cardoso oversaw an increase to 0.62 over his two terms (Figure 4.14).

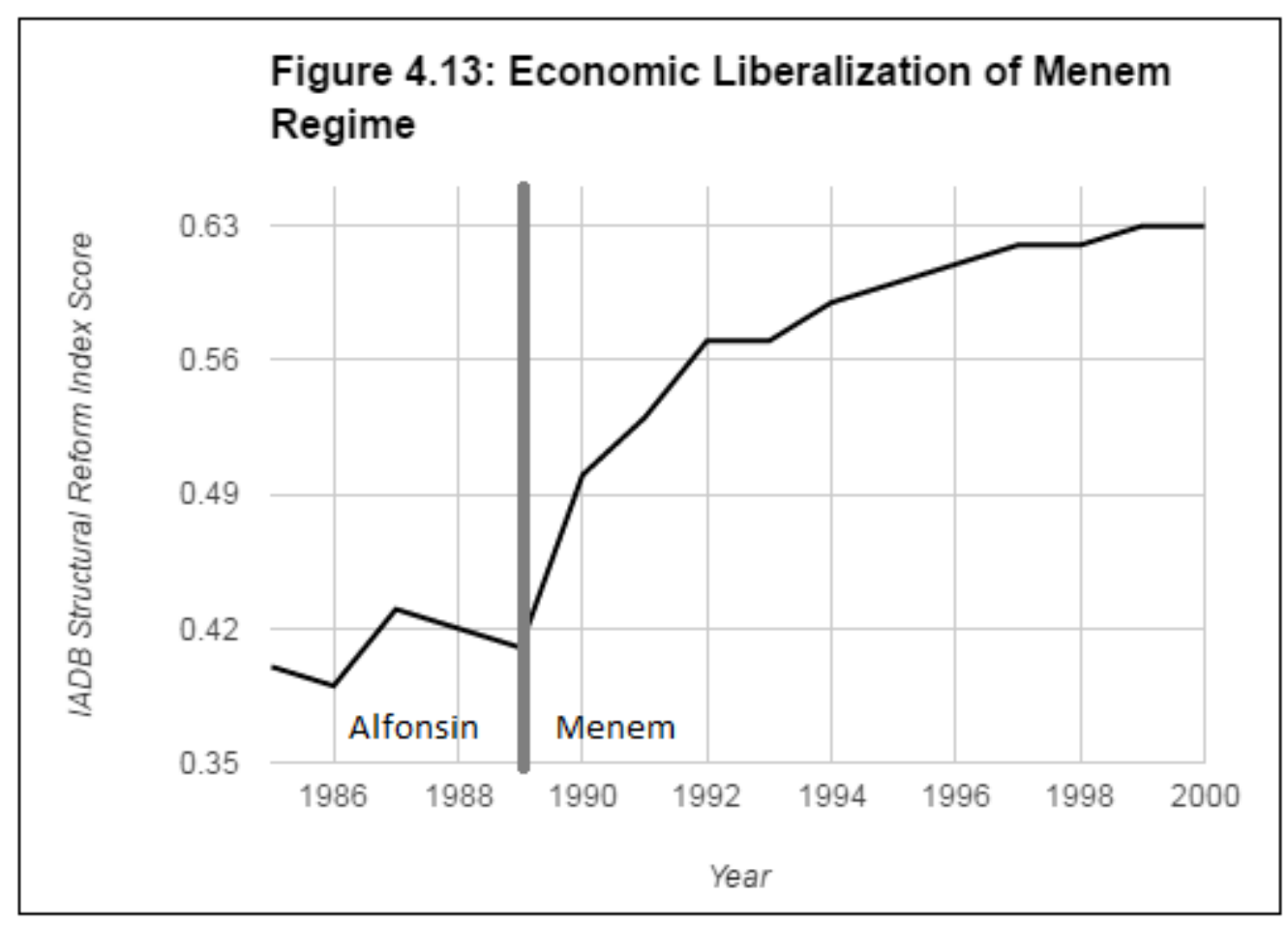




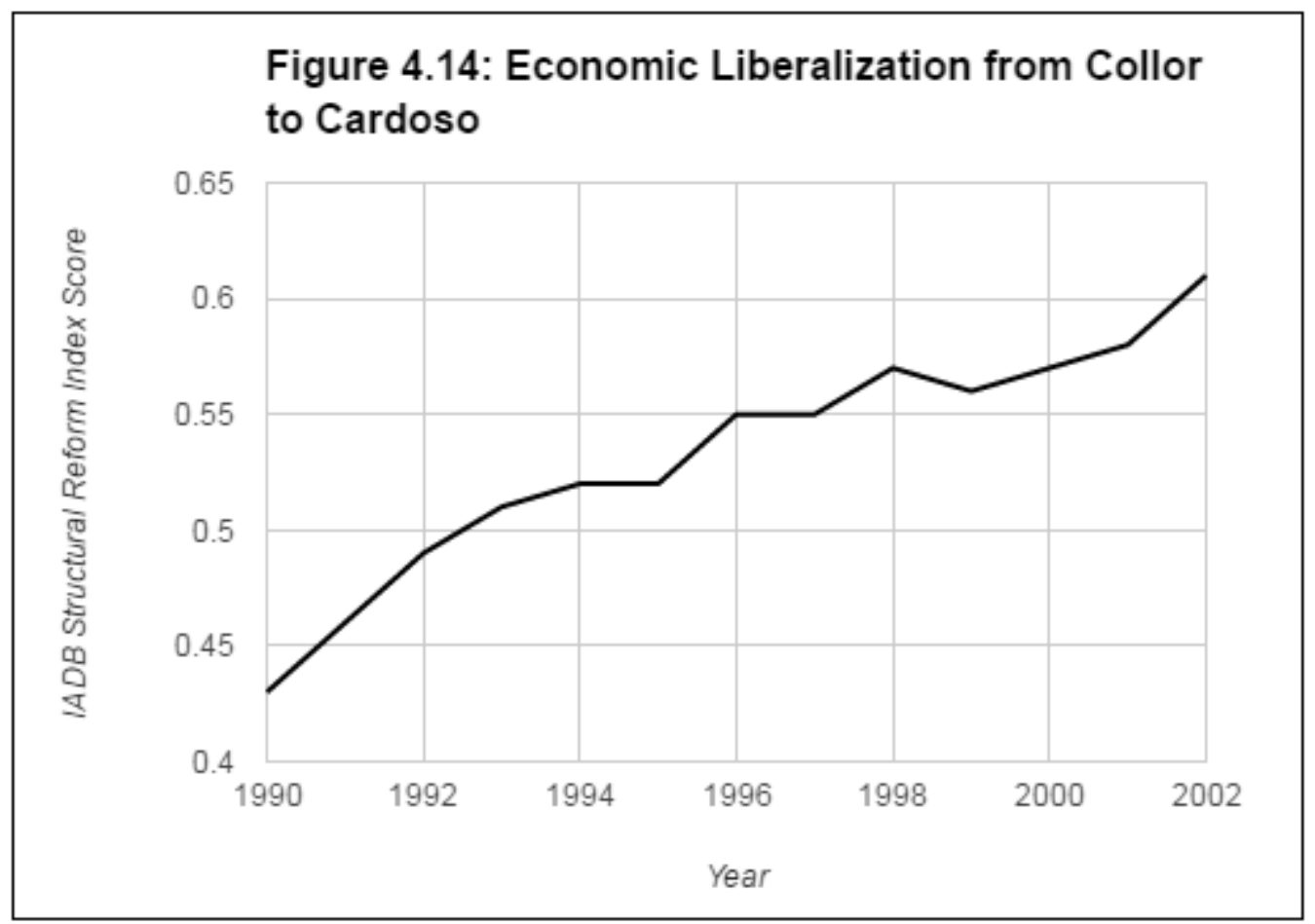

While some argue that Menem concealed his neoliberal objectives whilst campaigning (Pang 2001; Kingstone 2011), it may be more accurate to argue that Menem underwent a genuine philosophical shift right. "As governor of the Province of Rioja (1983-80), Menem ruled like a typical Latin American populist caudillo (Corrales 2002: 92). This change could thus be viewed as part of a general shift toward neoliberal development in the region or a genuine response to what could be seen as a collapse of the ISI development model and ensuing economic crisis. Even Domingo Felipe Cavallo, Menem's key economic adviser and staunch proponent of neoliberal economics, was not always so open to neoliberal economics. "It is worth mentioning that the doctoral 
dissertation of Cavallo severely attacked monetarism. Cavallo predicted that monetarism would fail in Latin America" (Pang 2001: 107).

Whatever the reasons, Argentina indeed underwent a severe liberalization during the 1990s. This economic opening was perhaps the most drastic shift from extreme statism and populism to extremely conservative reforms in all of Latin America (Pang 2001). Menem's reforms were generally more timid and slow with regard to labor than privatization, and social spending stayed roughly the same during this period. This is likely due to the legacy of a relatively strong labor movement in the country.

In Brazil, the literature suggests a strict adherence to the principles of the Washington Consensus: trade liberalization, financial liberalization, and privatization (Nassif and Feijo, 2013). Collor's term was not merely one of economic liberalization, but "marked the beginning of a trend towards the hegemony of finance in the economy and, consequently, in the state" (Bin 2014: 433). This is known as a period of financialization in which "short-term financial valorization dominates the rest of the economy, so that the decision-making criteria of the main financial agents and markets takes priority over production activities and defines investment and consumption decisions" (Medialdea 2013: 427). This economic financialization is argued to have led to Brazil’s “poverty trap” between 1993 and 2003. Brazil's liberalization continued through the abbreviated tenure of Franco as well as through the two terms of Cardoso, who "put finance at the top of the list of beneficiaries from the state's transfer payments (Bin 2014: 444). This continued Brazil's financialization. In 1998, Cardoso reached a 
deal with the IMF for $\$ 41.5$ billion. Such a deal implies Cardoso's adherence to the Washington Consensus and the neoliberal development model.

Income Distribution

How did this decade of democratic deepening and economic liberalization affect the functional income distribution in Argentina and Brazil? The data compiled for this thesis suggest a stark divergence in the trajectory of income distributions between Argentina and Brazil during this period. Unfortunately, reliable employment data is only available from 1993 onward for Argentina and 1992 onward for Brazil. However, the available data shows a net decrease in LS4 from 50.86 to 46.13 percent in Argentina and a net increase from 43.02 to 56.90 percent in Brazil during this period (Figures 4.15). 


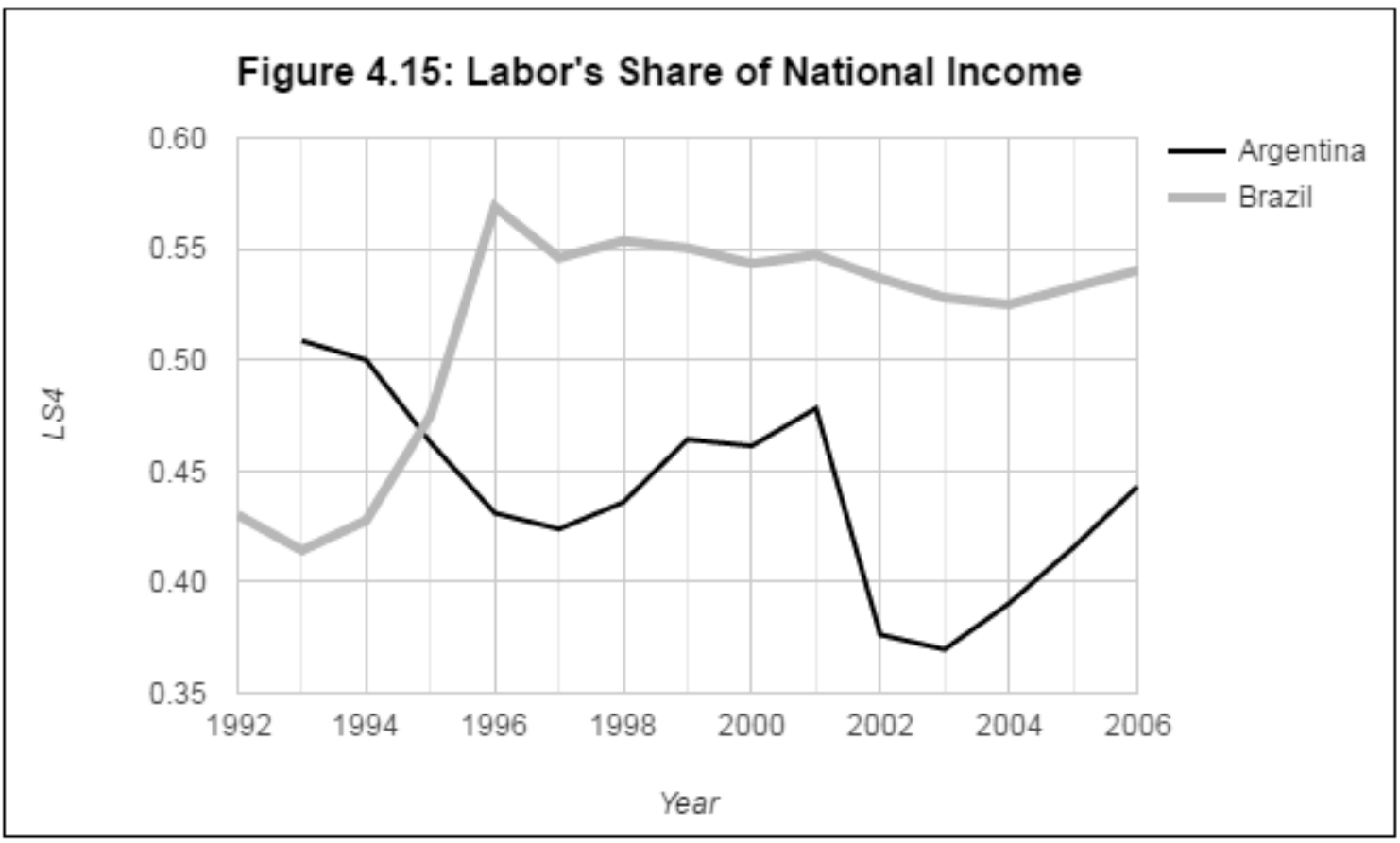

The data for Argentina suggests a turning point between 1996 and 1997 in which LS began to climb for the remainder of Menem's second term (and for the following year). This could have two possible causes: one external and one internal. First, Mexico's “Tequila Crisis” of 1995 seemed to have the regional effect of capital flight. Capital fleeing Argentina left labor's share of national income larger relative to that of capital. This type of improvement does not help the laboring class in absolute terms. The second potential cause of an increase in LS was a sort of crisis of democracy--the "re-reelection crisis."

After being re-elected in 1995, Menem began an attempt to alter Argentina's constitution to allow him to serve a third term. 80 percent of the Argentine people disapproved such a change and the backlash against Menem's plan to extend his rule 
arguably put Argentina's democracy in jeopardy (Corrales 2002: 215). This attempt by Menem led to a severe loss of political capital which caused his economic reforms to slow and their accomplishments to deteriorate. Menem's political overreach hurt his relationship with congress and created a "credibility deficit" which could have contributed causally to failed attempts at economic reform. To the extent that liberal economic reform in poor countries tends to disproportionately benefit capital and contribute to inequality, deterioration of such reforms should disproportionately harm capital and therefore inadvertently help income distribution. Therefore the slight rise in LS over the second half of Menem's second term may not have actually aided the absolute position of Argentina's impoverished population.

In fact, it is quite clear that throughout Menem's two terms capital improved its position relative to labor. Even the reduction of inflation between 1991 and 1994 was not beneficial across the board. "Inflation does not disappear automatically, and becomes even higher in some nontradables sectors. Within a few years, Buenos Aires became one of the most expensive cities in the world (comparable to Frankfurt), while it's wage levels lagged far behind (a third of Frankfurt levels)" (Corrales 2002: 193). The inflationary crisis that brought Menem to power disproportionately hurt labor--the broader and more poor segments of the population. The stabilization and boom of 1991 through 1994, however, hardly reduced poverty at all. Stability and prosperity, to the extent that Menem briefly delivered them, came unevenly. For instance, the automotive industry, communications, and retail gained ground during Menem's tenure. On the other hand, 
industries such as textiles and steel as well as transportation severely lost ground. Prosperity brought an influx of people into the formal labor force. More people looking for work, when combined with industrial reduction, led to increased unemployment. As some would have predicted, the neoliberal economic reforms enacted by Collor in Brazil would also benefit the population unevenly. Collor's BEFIEX--an export promotion law--'benefitted fewer than 50 companies in a country of 155 million people and an economy of $\$ 180$ billion in the 1970 s and a $\$ 414$ billion GDP in 1990. By accident the program helped foreign corporations more than domestic firms" (Pang 2002: 128). The result of the Collor Plan in fact hurt labor considerably. The Plan pushed Brazil into a deep recession including a large number of people losing their jobs. In Sao Paolo, 50,000 industrial workers were laid off. The minimum wage went down from $\$ 95$ to $\$ 65$ dollars per month. It seems that the middle class was hurt most by the Collor Plan. Brazil's implementation of neoliberal economic policies may have been successful at controlling hyperinflation, but they would end up "contributing to increased unemployment, informality, and constricting real wage growth" (Maia and Menezes 2014: 214). In short, The Collor Plan seems to have hurt Brazil's functional income distribution.

The effect of the Real Plan--put forth by the Franco regime--on income distribution is unclear. LS data shows a significant increase in labor's share of national income between 1993 and 1995, with LS4 increasing from 41.43 percent to 47.50 percent. This represented the beginning of a rise in LS that would last through 1996. The 
change in labor's share of national income during Cardoso's two terms is revealing. His first year in office saw the continuation of a rise in LS4 from 47.5 percent to its peak of 56.9 , where its three years of rapid gains ended abruptly and labor's share of national income stabilized through the rest of Cardoso's time in office. It is during this time that the financial sector separated itself from the rest of the population in terms of income (Maia and Menezes 2014). "The outcomes of the neoliberal and financial changes in the Brazilian economy since the Real Plan have been consistently unfavorable to the working classes. The gap between the labor and capital shares of total output has considerably widened in favor of the latter" (Bin 2014: 440). The value of financial assets increased drastically (Maia and Menezes 2014).

The literature paints an even grimmer picture than the LS data suggests. Under Cardoso, income inequality became significantly worse, situating Brazil below many African countries at the time based on the ratio of income between the top 10 percent and bottom 40 percent (Latin American Regional Reports: Brazil Report, 2001). The era is characterized as a period of poor growth with stagnant employment in which productivity increased at the expense of rising unemployment (Nassif and Feijo, 2013). Cardoso's term was one in which 'financial rent-seeking had 'hijacked' an excessively high proportion of income" (Maia and Menezes, 2014: 430). In contrast to those that view Cardoso's time as one in which Brazil reaped the rewards of globalization and the virtues of the neoliberal economic development model, critics point to the status of lower economic strata of the population. "Social instability, lack of civil liberty among the poor, 
police brutality, unequal income distribution, and the inability of congress and president to effectively solve the problems will remain intractable beyond Cardoso's term in office" (Pang 2002: 145). While the country may have gotten richer as a whole, labor and the poor were left behind in Brazil just as they were in Argentina.

\section{The New Millennium and the New Left}

On the surface, the 2000s have seen a political pivot leftward in the executive branch of both Argentina and Brazil. However, each country took different routes to get there. The political and economic climate of Argentina at the end of Menem's second term did not bode well for his party in the 1999 elections. "The uneven distribution of income, the government's inability to create jobs, and the perception that governmental institutions and officials are corrupt increased popular frustration that came to a head in the months of November and December [1999]" (Pang 2001: 120). This was the context

in which the elections were held that saw Fernando de la Rua of the Radical Civic Union party (UCR) stifle Menem's attempts to run for an unconstitutional third term. This was the context in which only the second non-Peronist, non-PJ affiliated politician took the executive office since 1972. Unfortunately, de la Rua's presidency cannot be seen as successful in light of the fact that he left office amid mass political and economic turbulence in the wake of the Argentina's 2001 economic collapse. De la Rua gave way 
to a revolving presidential door that would last until 2003. After winning a free, direct election in which Carlos Menem ran strongly, but eventually forfeited, Nestor Kirchner (PJ) assumed office seven months early. Kirchner opted not to run a second term with the intent of extending his influence through his wife, Cristina Fernandez. As anticipated, Fernandez de Kirchner won the 2007 election based heavily on the perceived success of her husband in achieving political stability and economic recovery

\section{(www.systemicpeace.org).}

Conversely, Brazil's alternation of the executive office occurred more smoothly than that of Argentina during this period. The 2003 Brazilian election brought about a leftward pivot--at least in rhetoric-- from the neoliberal model of Cardoso. After three unsuccessful campaigns, Luiz Inacio Lula da Silva of the left-leaning Workers' Party (PT), a former union organizer and one of the most popular Brazilian politicians of all time, won the Presidential office. He would serve two successful terms with a relative lack of turbulence.

\section{Level of Democracy}

As previously shown, the Polity IV index for Argentina and Brazil remained steady at +8 throughout this period. The democracies of Argentina and Brazil can therefore be seen as likely to be consolidated. However, both democratic regimes were weak and arguably defective (Merkel 2004). 
The crises in Argentina leading up to de la Rua's reign "revealed the existence of a profound crisis of legitimacy and democratic representation" (Carranza 2005: 76). Despite a steady Polity IV score, there is evidence to suggest Argentina's democracy was unhealthy before and throughout de la Rua's abbreviated term. In the October 2001 midterm elections for instance, 4 million people cast blank ballots. On December 19 and 20, 2001, there was a massive popular uprising leading to the resignation of the economic minister, Cavallo. Unable to contain the economic crisis handed to him by the Menem regime or the popular uprising in response to hyperinflation, de la Rua himself was compelled to resign from office early in late December 2001. Following his early exit, "protests and public pressure removed three interim presidents from office in less than a month--Frederico Ramon Puerta, Adolfo Rodriguez Saa, and Eduardo Oscar Camano" (Jouet 2998: 453). On January 2, 2002, congress chose Eduardo Duhalde (PJ), through a constitutional process, to serve as interim president through what was supposed to be the remainder of de La Rua's term. However, Duhalde would not last the rest of the term. By May 2003 public pressure compelled him to also step down early. Forced resignations such as that of de la Rua and the revolving presidential door suggest that Argentina's democracy was not of a particularly high level at this time leading up to the Kirchner era. In fact, Kirchner may have also had a negative effect on Argentine democracy. "Even though Kirchner [was] not the oppressive autocrat that Peron was, he hindered the progress of democratic transparency in Argentina by continuing to rely on political clientelism to consolidate presidential power" (Jouet 2008: 458). In the tradition of Latin 
American hyperpresidentialism, Kirchner clientelistically concentrated power into his own executive office.

Kirchner hurt Argentine democracy in several other ways. He tarnished judicial independence, not by bribes, threats, and stacking the courts as Menem did (Walker 2006), but by stacking the Council of the Magistrature, which selects and demotes the Supreme Court justices (Jouet 2008: 459). It is also clear that Kirchner planned to circumvent term limits. Instead of running for a second term, Kirchner had his wife, Cristina Fernandez de Kirchner, run in the 2007 elections. If she were to capitalize on his popularity and win, then he could wield influence throughout her term and run for a second, non-consecutive term himself. This would have led to a twelve year Kirchner dynasty in Argentine politics. Unfortunately for the Kirchners, Nestor died suddenly of a heart attack at age 60 during Cristina's first term in office.

Brazil's democracy at the turn of the millennium can also be seen as consolidated, yet defective (Merkel 2004). However, there is less evidence in the literature of democratic weakness within Lula's regime than that of the Kirchners.

Lula could attribute his success in the 2003 election to a failure of his predecessor. Cardoso's shift in public expenditure from a broad, middle-class focus to specifically targeting the poor in accordance with Washington Consensus principles led to the middle class shifting its votes to socialist candidates such as Lula (Wogart 2010: 396). The ability of the public to hold Cardoso's PSDB party accountable for this shift in focus, to sanction undesired political behavior, is evidence of a healthy democracy. 
Democratic dynamics may have brought Lula into office in response to Cardoso's perceived abandonment of the middle class, but the economic environment rendered him unable to deliver strongly on his populist, anti-finance campaign platform. During the campaign a crisis of confidence emerged in the financial sector, which saw Lula as a leftist who may have been willing to break contracts and violate property rights. This led to capital flight and a depreciation of the Real. In response, and against the mandate given to him by the people, Lula committed to keeping intact Cardoso's neoliberal macroeconomic policies of inflation targets, floating exchange rates, and primary fiscal surplus targets (Wogart 2010). In a sense, the financialization and liberalization of the Brazilian economy mitigated Lula's ability to deliver on his campaign platform.

\section{Political Performance}

The degree of governance and change thereof differed between Argentina and Brazil during this period. In Argentina, Menem left office with a very low RPE score of 0.729. De la Rua and the four subsequent Argentine presidents failed to improve the government's performance in a significant way. When Kirchner took office in 2003, Argentina's RPE score was 0.739 . By 2008, it had reached 1.164 . This was an increase of 58 percent, which brought Argentina back above the global average in this measure political capacity (Figure 4.16). While RPE data only extends to 2011, it appears as though Cristina Fernandez de Kirchner oversaw a slight and continued increase in 
political performance. In contrast, when Lula took power in Brazil in 2002, the country's political capacity of 1.370 was already significantly greater than that of Argentina.

Throughout Lula's two terms as president, Brazil's political capacity remained high with no discernable trend (Figure 4.17).

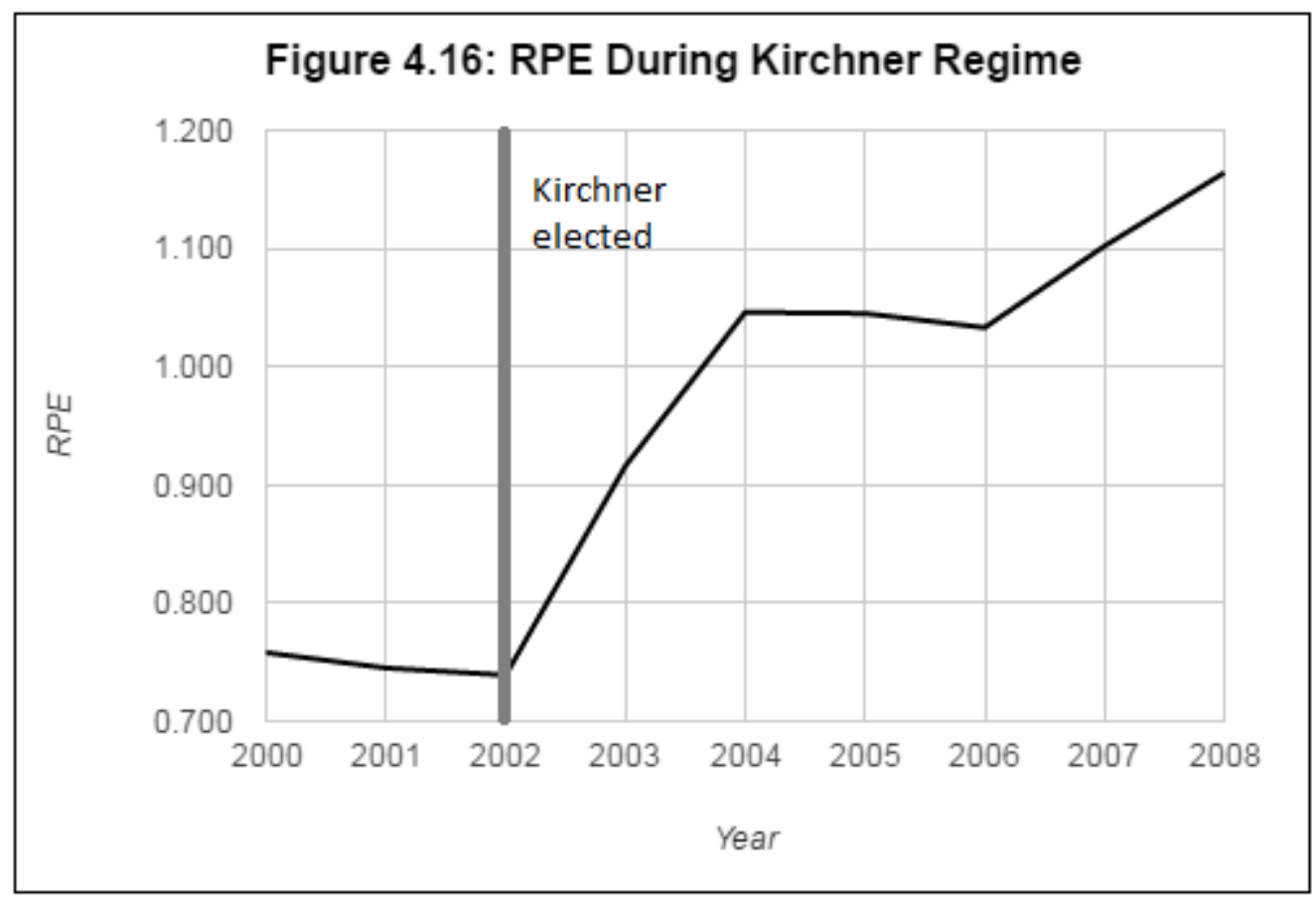




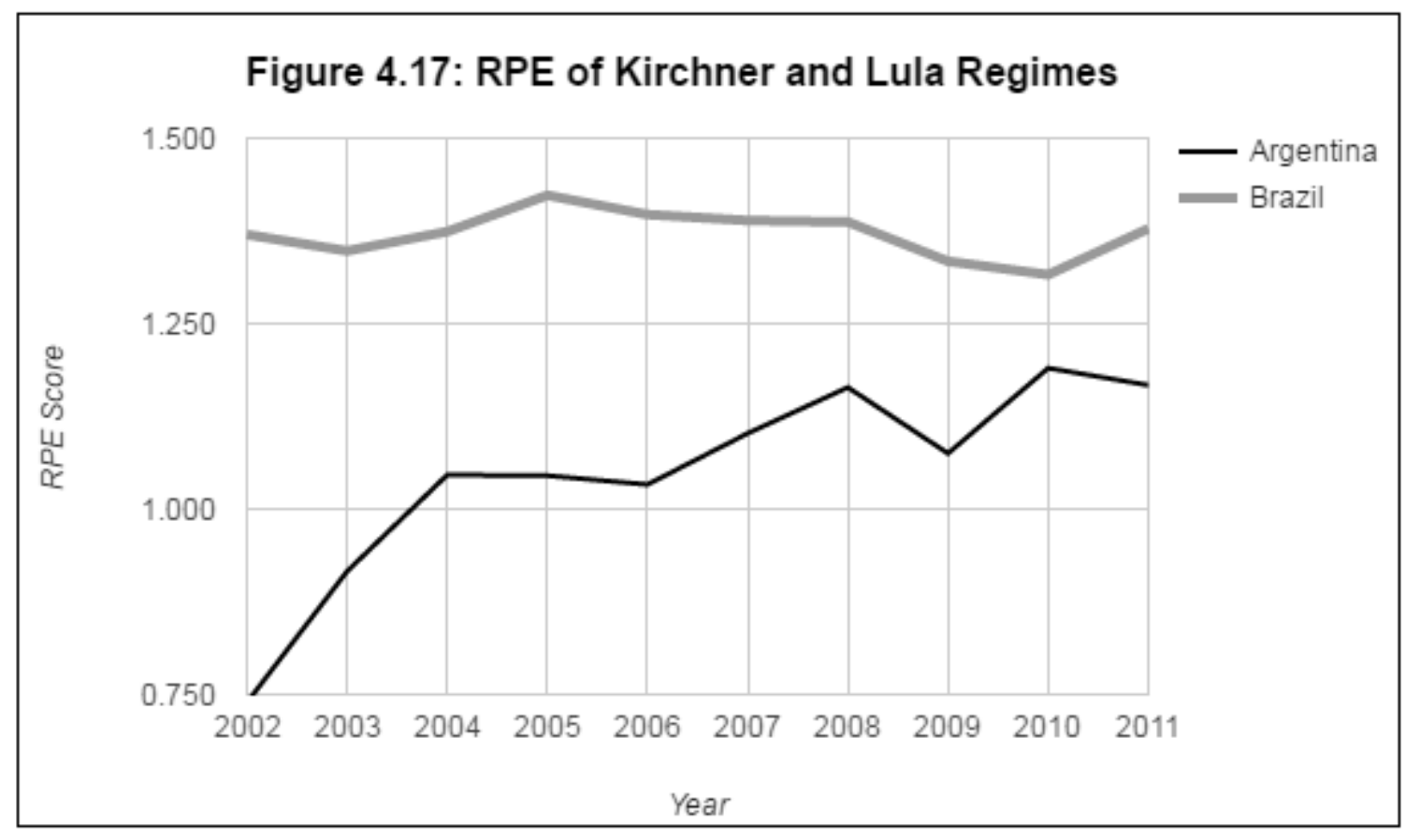

\section{Corruption}

While Argentina and Brazil both experienced high levels of corruption in line with the rest of Latin America at the time, Brazil was consistently less corrupt than Argentina during this period (Figure 4.18). 


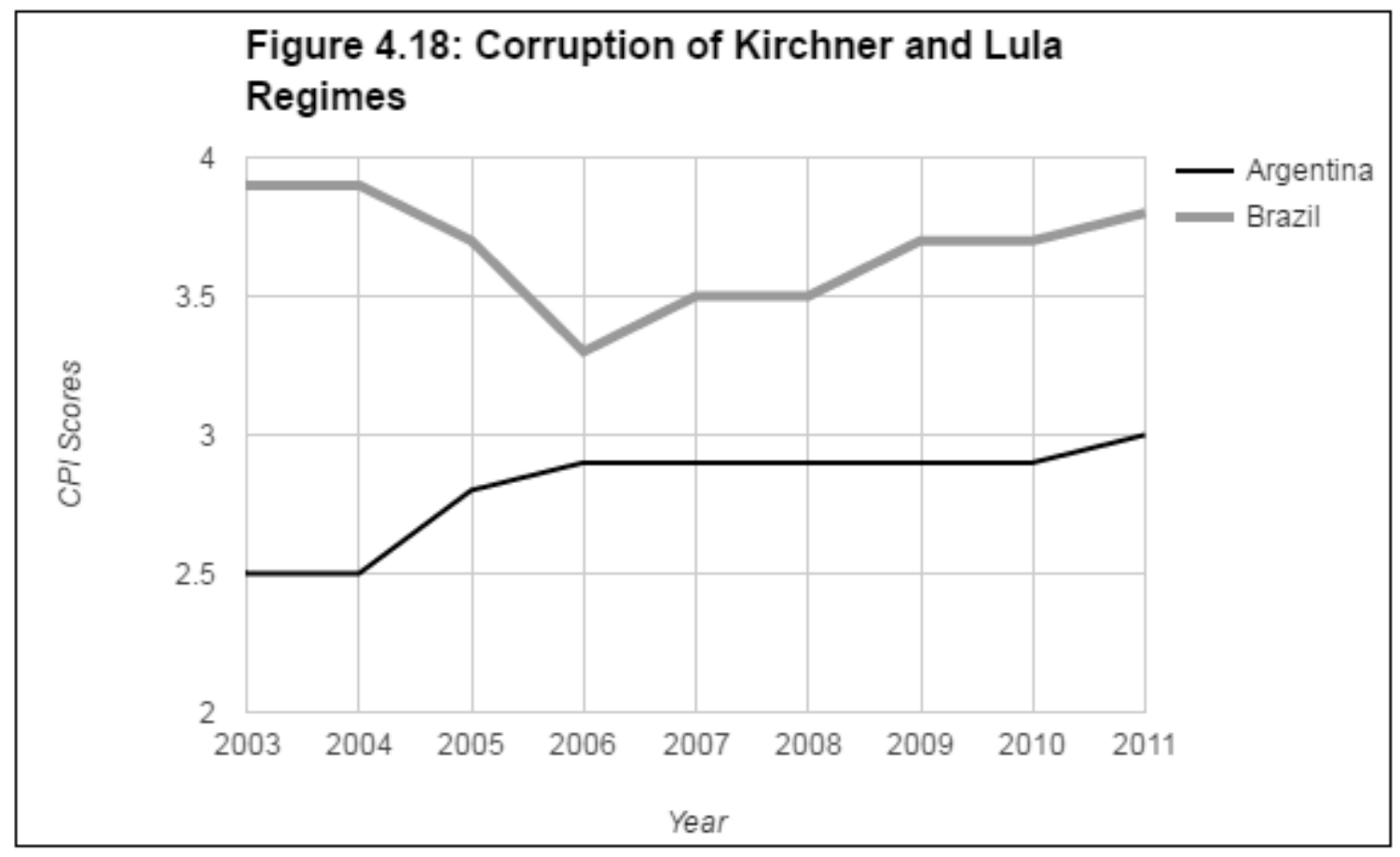

In Argentina, Menem left office with a high level of perceived public corruption represented by a CPI score of 3.5. During the abbreviated tenure of de la Rua and subsequent revolving presidential door period, Argentina's CPI score decreased to 2.5 representing a 29 percent increase in perceived corruption according to the index despite the fact that de la Rua campaigned on wiping out the corruption of the Menem regime. This is unsurprising given the public uproar throughout his abbreviated term and beyond. Corruption in the de la Rua regime also harmed policy implementation. For instance, congress approved labor reform in May of 2000, but a corruption scandal in which Vice President Carlos Alvarez was forced to resign served to weaken government to the point of being unable to implement the reforms (Carranza 2005: 70). 
The terms of Nestor Kirchner and Cristina Fernandez de Kirchner coincided with a decrease in corruption. In 2003, Argentina's CPI score was 2.5. By 2008 it rose to 2.9, representing a decrease in corruption of 0.4 units. However, "several corruption scandals suggest that the Kirchner administration did not refrain from bribery in order to solidify its grip on Argentine society and enrich itself” (Jouet 2008: 459). Among such scandals include the accusation of bribery by a Swedish gas pipeline company as well as an incident in which $\$ 64$ thousand in cash was found in the bathroom of the Minister of the Economy. Old habits die hard. Argentina's history of corrupt public officials is no exception.

When Fernandez de Kirchner took office, Argentina's CPI score was 2.9. While the trend appears to have been toward a decrease in the perception of public corruption since then, Transparency International altered its methodology in 2012 (mostly by scaling up by a factor of 10), possibly making data prior to that year incomparable to data since (Figure 4.11). Nevertheless, in 2004, Argentina scored a 34 out of a possible 100, earning it a rank of 107th out of 175 countries indexed. Transparency International (2014) suggests that, despite the presence of institutions tasked with fighting corruption, there are gaps between anti-corruption laws and their actual enforcement. These gaps are argued to be among the greatest "corruption risks." Transparency International also argues that there is a lack of transparency in campaign financing and that the judiciary suffers from political influence--a consistent problem throughout Argentina's history. 
While the perception of public corruption was consistently lower during the Lula regime than that of the Kirchner regimes, it was not absent during the Lula era. In fact, it is during Lula's first term that Brazil's CPI score plummeted more sharply than any period before or after. Lula's second term ushered in a decrease in the perception of public corruption which would persist through the latest available data (Figure 4.18). It is unclear what sparked this change of course, but the data seems to suggest that the increase in perceived corruption was a remnant of the Cardoso regime and that Lula in fact help to cause the rebound and sustained decrease which appears to have begun in 2006.

\section{Development Strategy}

Both the Kirchner and Lula regimes could be seen as a pivot, at least in rhetoric, away from the neoliberal Washington Consensus and toward a new Left with regard to economics. However, while each executive campaigned on relatively left-leaning economic platforms, neither regime actually represents a retrenchment from the two prior decades of economic liberalization.

Kirchner's economic strategy is referred to in the literature as "neodesarrollismo" or neo-developmentalism (Wylde 2011). It was a sort of open-economy nationalism that incorporated neoliberal elements as well as a strong dose of nationalism and statism. It was a shift from, and likely a reaction to, the perceived effects of Menem and de La 
Rua's relatively pure neoliberal policy aims. However, Kirchnerism maintained "a practical acceptance of some of the policies and principles associated with neoliberalism" (Wylde 2011: 439). Specifically, it maintained the neoliberal welfare model of social safety nets geared toward minimizing the harshest poverty and indigence. This is in contrast with classic Peronism, in which clientelism was directed toward the poor and working class as a whole.

Lula, a former labor organizer and member of the left-leaning Workers' Party, represents a shift in Brazilian political economy. However, that shift was perhaps not as significant as Lula or those that voted him into office may have preferred. "Despite the traditional (leftist) anti-creditor rhetoric of Lula's Workers' Party, his presidency marked a deepened Brazilian commitment to paying the interest on its public debt" (Bin 2014: 438). This contradiction between populist rhetoric and at least partial adherence to the Washington Consensus is reminiscent of Menem's ideological shift after being elected. Nevertheless, in the face of a neoliberal and financialized climate, Lula did make efforts at controlling the economy, leading to what was arguably the first modern Brazilian regime with such contradictory features. "Even under the neo-liberal macroeconomic agenda, there was an attempt to restore an agenda of industrial and technological policy" (Nassif 2013: 566). Indeed, while the IADB structural reform index score for Brazil rose from 0.62 to 0.66 by 2008, it remained there through the remainder of available data (Figure 4.19). 


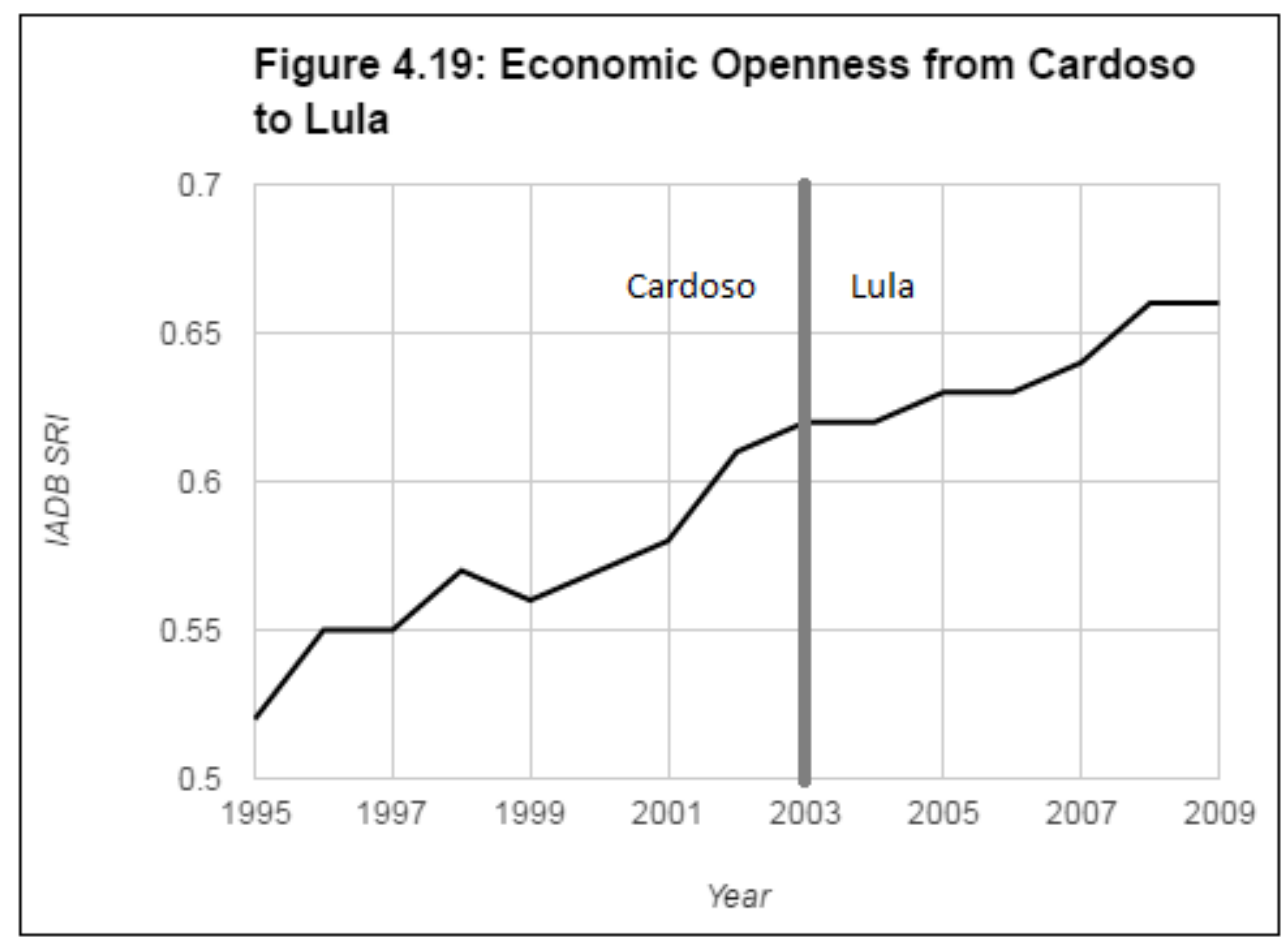

While Kirchnerism treated welfare in the neoliberal fashion, it differed starkly from both Menem's neoliberal agenda and the classic Peronist ISI developmental model. Unlike the hands-off approach to trade encouraged by the neoliberal model, Kirchner pursued an active industrial policy, protected infant industries and very much played an active role in the market and prices. Unlike the Peronist development model, Kirchner's economic policies promoted export in a similar way to the Asian Tiger economies. Kirchner's regime can also be seen as neo-corporatist, in contrast to Peron's, in the way that it more genuinely incorporated the business community's interests and voice in its policy formation (Wylde 2011). As a result, Argentina's IADB Structural Reform Index score rose slightly from 0.62 to 0.65 during the course of Kirchner's reign (Figure 4.20). In sum, while both Kirchner and Lula are seen as part of the new Left of Latin America, 
it is clear that both presidents oversaw the continued liberalization of their respective economies over their two term tenures.

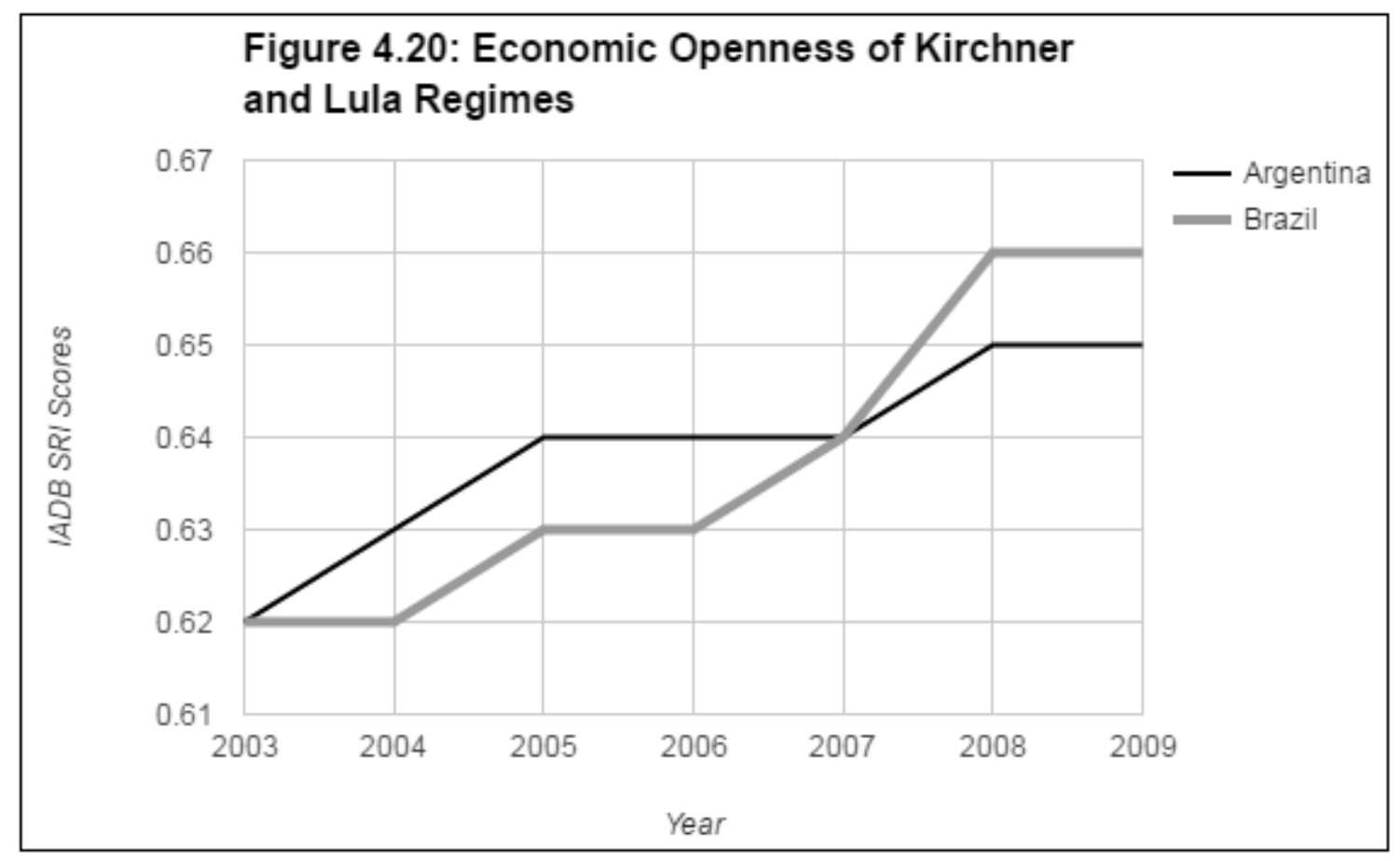

Income Distribution

Both Lula and Kirchner oversaw an increase in labor's share of national income and therefore an improvement in economic inequality. However, their economies were in vastly different situations when each took power. Whereas Lula took over after Cardoso's two relatively calm terms in office, Kirchner took the executive office following years of massive economic and political turbulence. It is also unclear whether the gains that 
Kirchner and Lula made were sufficient relative to the high levels of poverty and inequality that each faced and the efforts that each put in.

When de la Rua took power from Menem in 2000, Argentina was in a period of hyperinflation culminating in a $\$ 100$ billion default combined with corruption, poor political performance, and a neoliberal reform agenda which hurt income distribution, decreased labor's share of national income, and caused great suffering among much of Argentina's population. Argentina's LS4 was 46.13 percent in 2000. After peaking at 47.82 percent in 2001, LS4 plummeted sharply to 37.63 percent by 2002. In other words, labor lost more than one fifth of its share of national income in just one year. By 2003 labor's share of national income was at an all-time low. When de la Rua left office, fifteen million out of Argentina's thirty-seven million people lived in poverty (Jouet 2008: 450).

By the time that Kirchner took office, LS4 had reached an all-time low of 37.63 percent. Kirchner's export-driven approach to economic development with a focus on industry over banking and capital markets led to a significant increase in functional income equality. In 2003, LS4 was at 37.0 percent. By 2006--the last year for which this data is available--LS4 had increased to 44.3 percent and appeared poised to continue its ascent (Figure 4.21). 


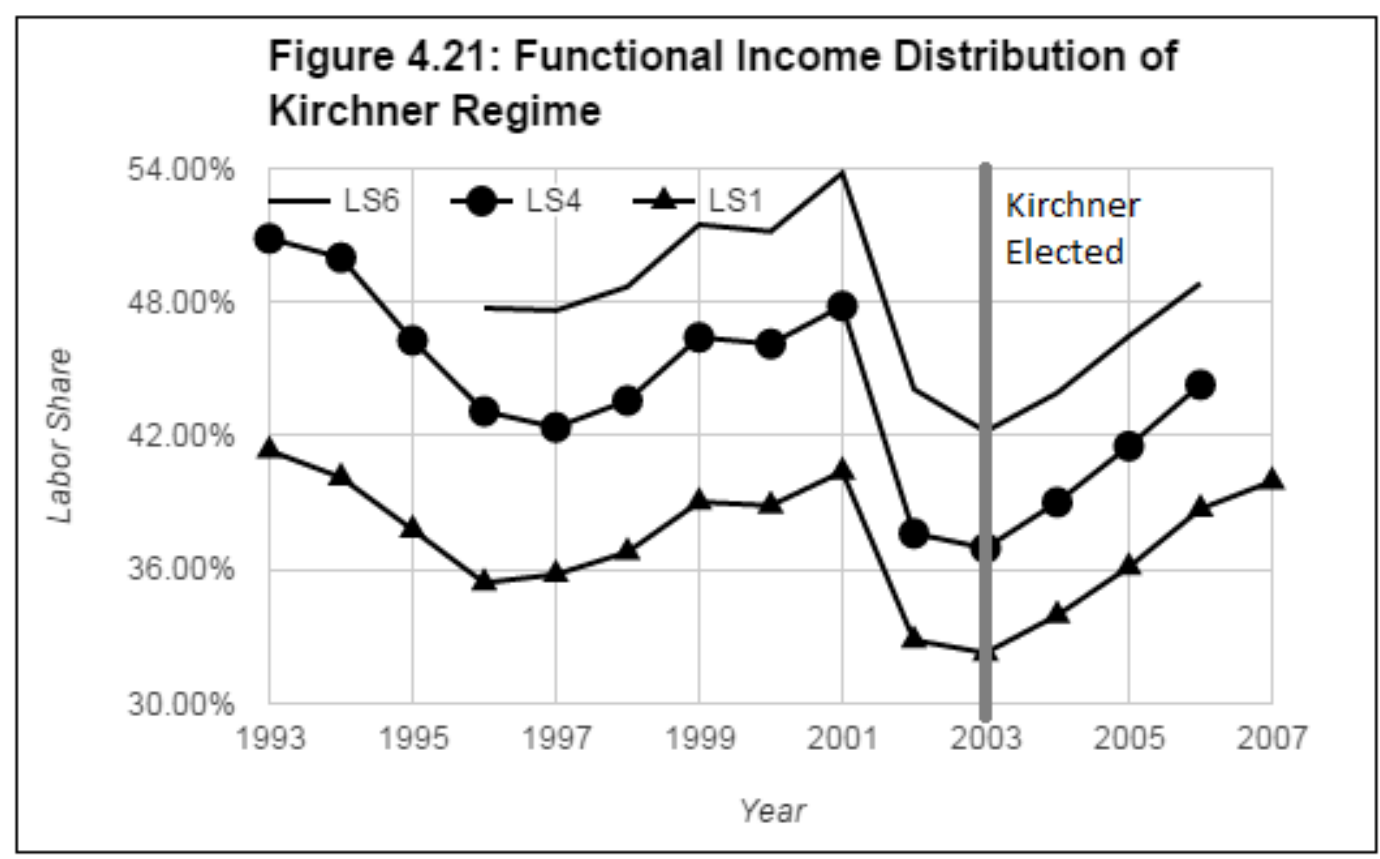

It is not a stretch to argue that the reign of Cristina Fernandez de Kirchner can be viewed as an extension of her husband's policies. While there is no data on LS beyond 2007, Argentina's GINI index score had steadily decreased from 2000 through at least 2011, while the percent of national income earned by the bottom 60 percent of workers steadily increased (World Bank). Therefore, it is safe to say that the piece of the economic pie distributed to labor has increased relative to that of capital throughout the Fernandez de Kirchner regime just as it did during Nestor Kirchner's term.

On the surface, this movement toward a more equitable income distribution would be predicted to have alleviated the developmental suffering of the Argentine masses. Unfortunately, however, poverty remained high and inequality actually increased between 2003 and 2007 (Jouet 2008: 454; Wylde 2011: 240). The gains achieved by the Argentine people can arguably be attributed to the economic recovery rather than 
addressing the poverty and inequality created by the neoliberal policies of the 1990s. Nevertheless, the poverty and inequality that runs rampant throughout Latin America was not tackled by the Kirchner regime. "Inequalities increased or simply stayed the same depending on the sector, and the structures of socio-economic power stayed in place. Therefore Kirchner has not distributed property, income, or power--except among different segments of the capitalist class" (Wolfe 2011: 446).

In Brazil, Lula oversaw a definite increase in Labor's share of national income. LS4 increased from 52.8 percent in 2003 to 54.9 percent by 2007 . LS1--a more rudimentary calculation, but one with data extending to 2009--shows a continued increase in labor's share through Lula's second term (Figure 4.22).

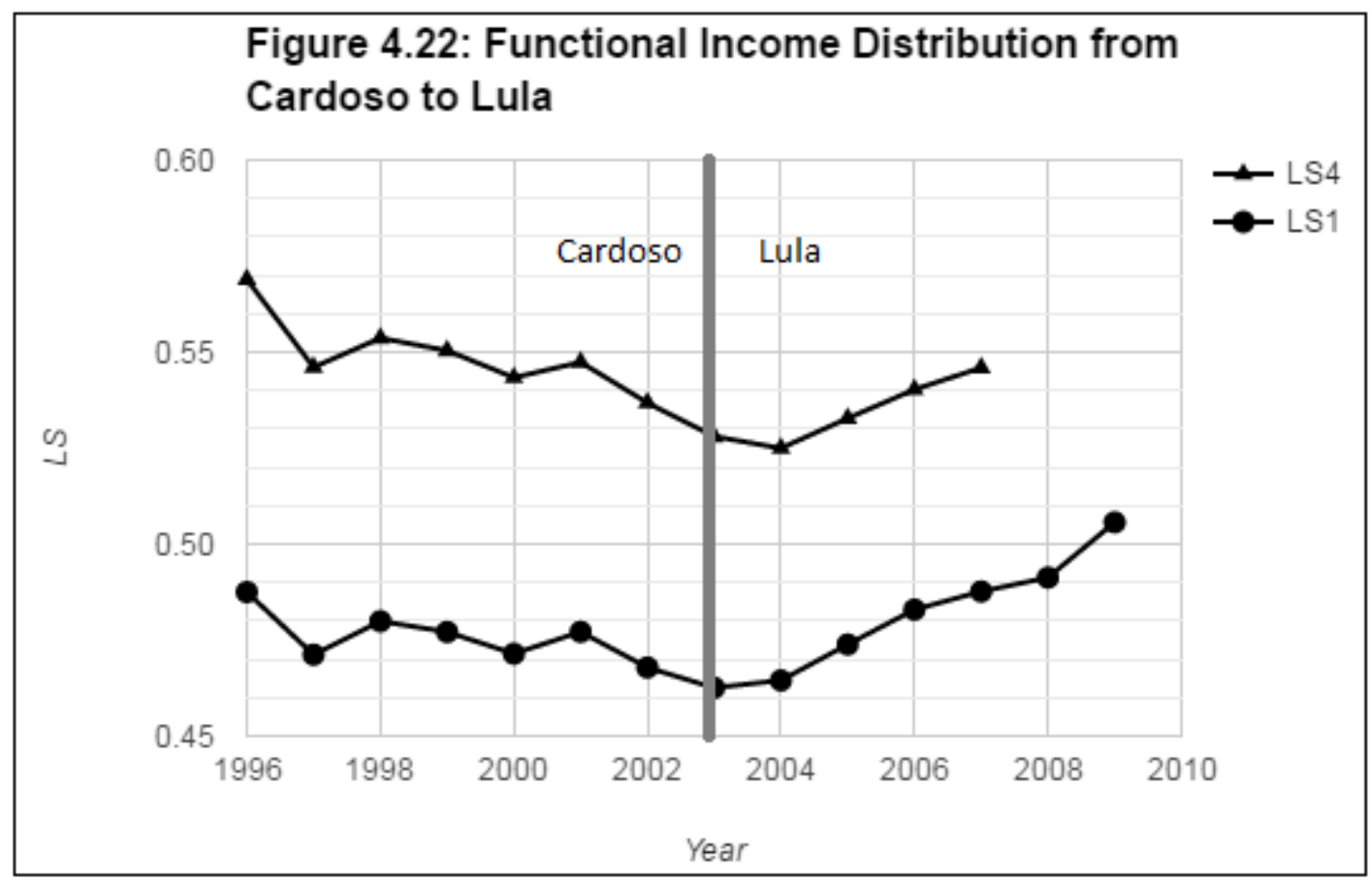


The 2000s saw a fast increase in wages and decrease in unemployment in Brazil (Maia and Menezes, 2014). Of those gains, agriculture was the most dynamic sector, whereas urban industrial workers' plight improved more slightly (Wogart 2010). Critics argue that Lula's effects on income inequality were small given the massive effort of Bolsa Familia and the increasing education and job opportunities in the recently stable economic environment (Wogart 2010). They argue that since 2005 real wages have grown faster than labor productivity due in part to a decreased supply of skilled labor force (Maia and Menezes 2014). Nevertheless, socioeconomic inequality remains stark despite modest improvements. Brazil is still among the most unequal societies in the region (Kingstone 2011; Wogart 2010). Like the Kirchner's, Lula's two terms as Brazil's president--despite showing some progress--seem not to have been the panacea to starkly unequal income distribution.

\section{Analysis}

What do these findings suggest regarding the relationship between democratization and functional income distribution in Argentina and Brazil? Two decades have passed since Argentina and Brazil transitioned to democracy. Neither transition seems to have been immediately followed by an improvement in income inequality. Nor has the inequality been alleviated on a whole in the two decades since. In 
fact, there is no evidence of labor gaining relative to capital in either country until at least the third democratic president's tenure ${ }^{5}$.

One might expect, as discussed in the previous chapters, that democratization would make policymakers more accountable to labor because labor makes up the broadest segment of the population. This increased public accountability would thereby increase labor's share in national income. "On a whole, however, democracy...has brought about less reallocation of resources than one might expect" (Hunter and Sugiyama, 2009: 40). Democracy may have improved the welfare of large segments of the poorest members of Argentina and Brazil, but seldom at the cost of finance and capital.

While LS has increased steadily in each country since 2004, income distribution in Argentina and Brazil had followed divergent paths in the prior decades (Figure 4.23). Perhaps the most important period to this research is from 1993 to 1996. Figure 4.23 illustrates that this period was one in which LS in Argentina declined while LS in Brazil increased rapidly. What caused these two neighboring countries to experience such opposite changes to income distribution?

\footnotetext{
${ }^{5}$ Kirchner in Argentina, Franco in Brazil.
} 


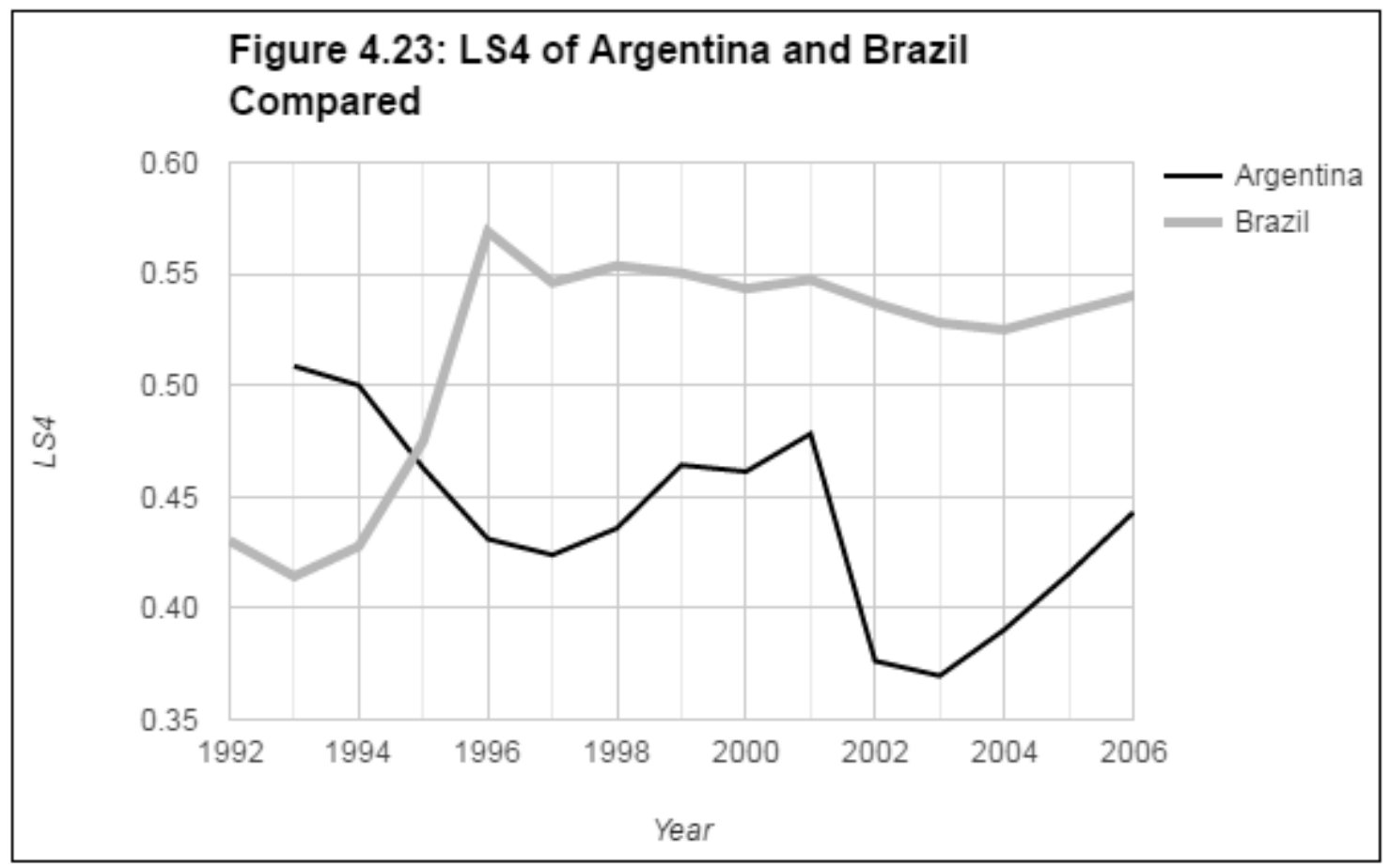

First, Brazil was more democratic than Argentina during this period as well as in the years prior. Brazil maintained a +8 on the Polity IV index from 1988 onward, whereas Argentina dipped to +7 from 1989 to 1998 (Figure 4.1). The Polity IV threshold for the category of "democracy" is +6 and above, and Argentina therefore never lost its status as a democracy. However, this index suggests that during this period Brazil was more democratic than Argentina. This fact lends some support for the hypothesis presented in the previous chapter--that there is a positive, causal relationship between level of democracy and labor's share of national income.

Second, Brazil's political performance scored much higher than Argentina's. Argentina's RPE score took a major hit from 1992 to 1993 corresponding with Menem's run for re-election amid rampant corruption. In contrast, Brazil enjoyed a higher RPE 
score than Argentina, which was also on the rise from 1992 to 1995. Theoretically, a government with a higher political capacity should be more able to implement whichever social or economic policies it chooses. Therefore, all else equal it makes sense that Brazil's income distribution improved relative to that of Argentina during a period in which it outperformed Argentina politically.

The third factor of apparent significance is corruption. As previously stated, Menem's regime was plagued by corruption, perhaps more than any other regime covered in this research. CPI scores for Argentina and Brazil in the period leading up to 1993 reveal a rapid rise in corruption in Argentina while Brazil's corruption decreased. Clientelism, the form of corruption endemic to the Menem government, tends to divert government funds and shape the political and economic landscape in a way that favors the few at the expense of society at large. Therefore, corruption is a likely causal factor in the differing LS trajectories of Argentina and Brazil from 1993 to 1996.

The effect of development strategy on functional income distribution seems less clear. In 1989, Brazil's IADB structural reform index score was, for the first time, higher than that of Argentina. However, from 1989 to 1993, Argentina opened its economy at a significantly faster rate than Brazil. In fact, this was perhaps the most extreme period of economic liberalization in the entire region (Pang 2001). To those that argue Washington Consensus based reforms contribute to income inequality, it comes as no surprise that Menem's extreme neoliberal pivot preceded the major decline in LS. However, Brazil also underwent economic liberalization in the years leading up to this period. Also, from 
1993 to 1996, both countries liberalized at identical rates. This suggests that economic liberalization may not, by itself, have a significant, direct impact on functional income distribution.

The respective functional income distributions of Argentina and Brazil also differed in trajectory from 1996 to 2001. During this period Argentina's LS4 increased from 43.1 to 47.8 percent, whereas Brazil's LS4 decreased from 56.9 to 54.7 percent (figure 4.23). Both countries' income distributions reversed course from the previous period. Similar patterns emerge. Argentina's Polity IV index score increased from +7 to +8 from 1998 to 1999. Argentina's increase in its level of democracy during this period corresponds with a positive change in course of its functional income distribution.

The relationship between political performance and functional income distribution is unclear when comparing the change in RPE scores to the change in LS4 from 1996 to 2001. Argentina increased its RPE from 0.66 to 0.75 during this period, corresponding with an increase in LS4 from 43.1 to 47.8 percent as expected. But surprisingly, Brazil's RPE score increased much more significantly, from 0.94 to 1.27 , while its LS4 actually decreased from 56.9 to 54.7 percent. This may seem to suggest a negative or insignificant correlation between RPE and LS4. However, if RPE were related causally to LS4, one would expect to see the effects on income distribution to lag slightly behind changes in political capacity. Indeed, when comparing the graphs of RPE and LS4 for these two periods, a striking pattern emerges (Figure 4.24). It becomes clear that changes in the trajectory of RPE consistently precede the major changes in LS4 by roughly two years. 
This suggests that political capacity positively affects functional income equality. Also, while the trajectories of RPE and LS tend to correspond, when comparing Argentina and Brazil's positions relative to each other, the pattern is even clearer. Argentina enjoyed higher political performance than Brazil from 1990 to 1993 and a more equitable functional income distribution than Brazil until 1995. In 1994, the RPE score gap between Argentina and Brazil was at its widest. This corresponds with the widest gap between LS4 two years later. 


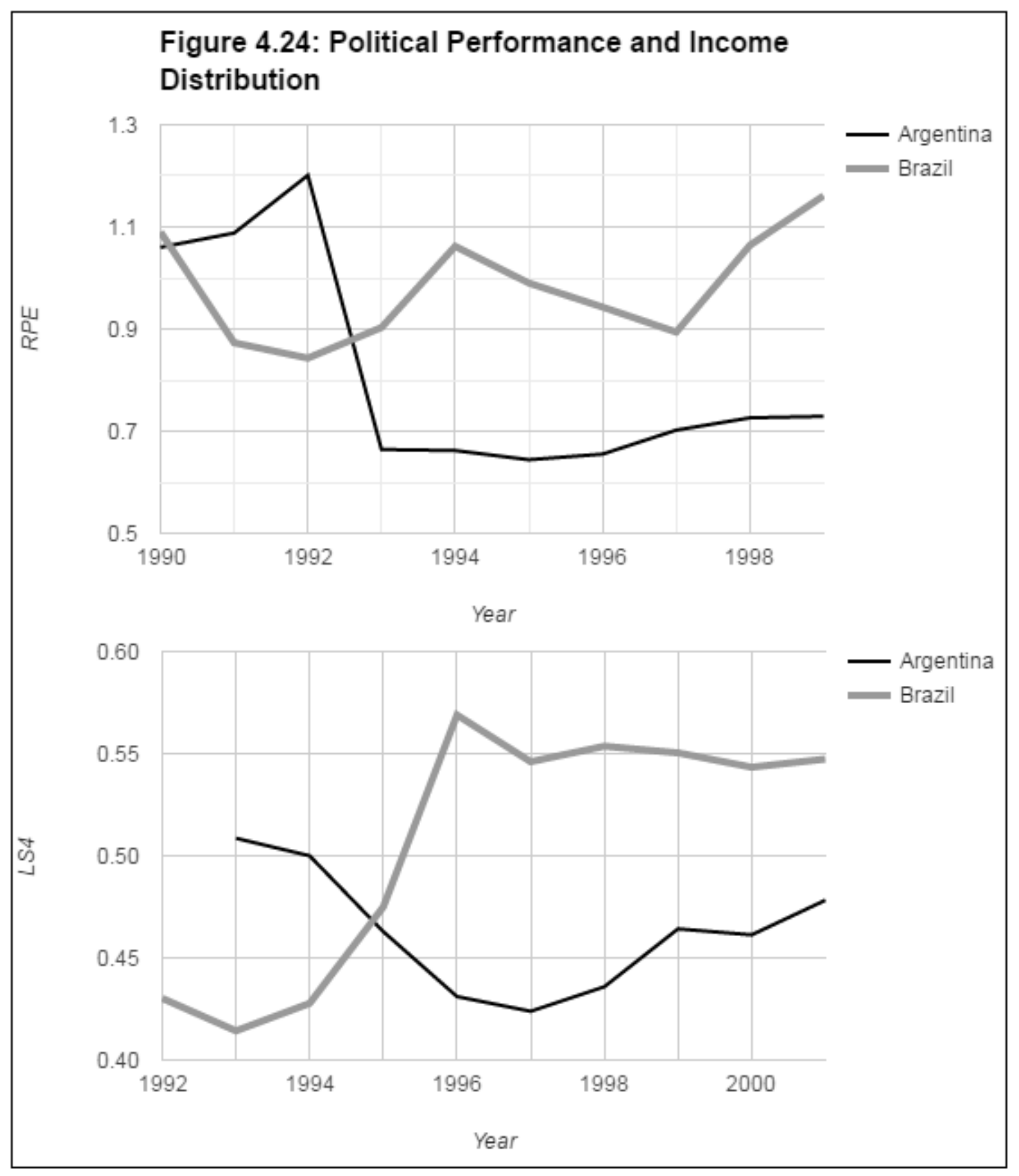

The position of Argentina relative to Brazil with regard to RPE is predictive of their relative positions regarding LS4 roughly two years later. This relationship appears 
more significant and consistent than the relationship between democracy and income distribution when considering the data presented in this research. Brazil's authoritarian era was characterized as one of upward mobility. Menem's regime increased Argentina's level of democracy, but saw an increase in functional income inequality. Both Argentina and Brazil have consolidated democracies, yet neither have seen a significant net increase in Labor's share of national income over the past two decades. Perhaps this is due to the mediocre or defective qualities of the Brazilian and Argentine democracies as demonstrated by the fact that neither has been able to increase their Polity IV index score above +8 . In fact, the literature suggests that as of 2002, both Argentina and Brazil could be categorized as defective democracies (Merkel 2004). Argentina is arguably a "Delegative democracy," whereas Brazil is an "Exclusive, Illiberal Democracy." Nevertheless, the level of democracy as operationalized in this research appears to have a less consistent impact on functional income distribution than does political performance.

Unlike RPE, corruption appears to follow rather than lead the path of LS. For example, Brazil's LS4 peaked at 57 percent in 1996, followed by a peak in Brazil's CPI score at 4.1 three years later. By 2004, Brazil's LS reached a low of 52 percent before increasing gradually to the present. This was followed two years later by Brazil's CPI score, which reached a low of 3.3 in 2006 before also increasing gradually to the present (Figure 4.25). Argentina's LS4 and CPI scores show a similar pattern. This refutes the argument that corruption is a causal factor in income inequality. Rather, it seems to 
suggest that--if there is a causal relationship--income inequality may be a causal factor in corruption.

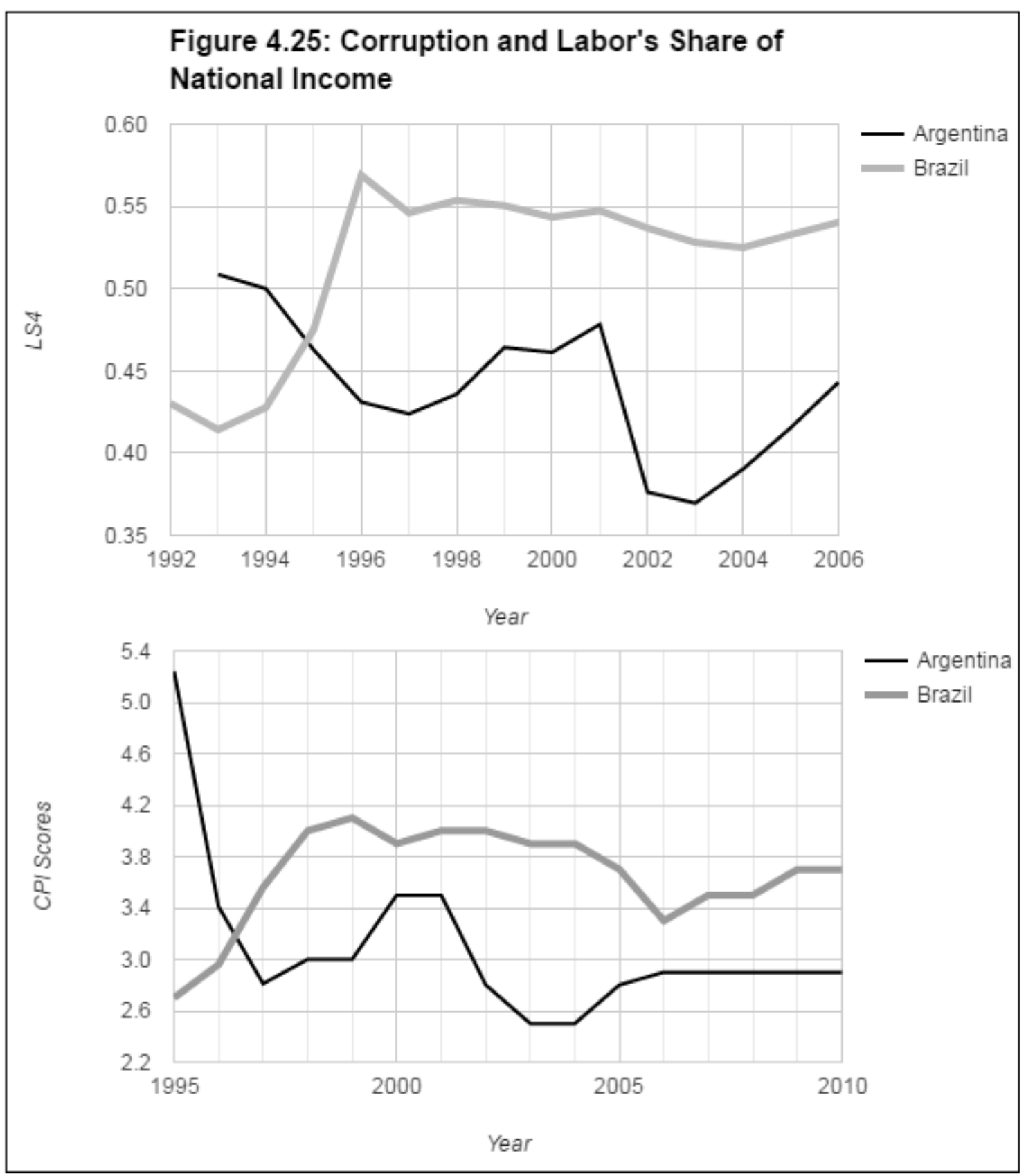


This chapter presented qualitative data and descriptive statistics for each presidency in Argentina and Brazil since their most recent bouts with authoritarianism in an attempt to answer whether democracy improves functional income distribution in developing countries. It found little evidence to support this hypothesis. The direct effects of development strategy on functional income distribution are unclear given that there has never been a meaningful retrenchment from the process of economic opening in either country, though Lula and the Kirchners were the most populist rhetorically and their terms coincided with the increasing equality. Perhaps the most significant finding was what appears to be a causal relationship between political performance and functional income distribution: the former seems to predict the latter. It is therefore likely that the degree of governance or political capacity has a greater effect on equitable development than does the type of governing body. The concluding chapter will discuss limitations, policy implications, and areas for further research. 


\section{Chapter - 5}

Conclusion

This thesis attempted to contribute to the existing literature on democratization, political performance, and economic development by examining Argentina and Brazil from their most recent bouts with authoritarianism to the present. For this purpose, it compared several dynamic indices including the Polity IV index, Relative Political Extraction, the Corruption Perception Index, and the Inter-American Development Bank’s Structural Reform Index. It also used data from the International Labor Organization's Yearbook of Labor Statistics and the United Nations National Accounts Statistics to chart the functional income distribution from each country during the period in question. Its aim was to assess whether it was democratization or political capacity that affected the shape of development in the two countries in question. In the end, this thesis failed to find evidence to confirm that democratization caused a more equitable functional income distribution. The findings do suggest, however, that functional income distribution is affected by political performance.

The first pair of hypotheses pertained to the specific effect of an increase in the level of democracy — as measured by the Polity IV index — on labor's share of national income in Argentina and Brazil. This research did not find sufficient evidence to accept the hypothesis that an increase in the level of democracy positively affects LS. Reliable, quantitative data on LS is unavailable for the authoritarian periods and periods of transition from authoritarianism to democracy. For the period in which LS data is available, the trajectory of LS in Argentina and Brazil differ despite the fact that their 
Polity IV scores are equal for most of that time. Taking the whole period studied in this research as a whole, neither country seems to have improved functional income inequality despite transitioning to and consolidating their democracies.

The second pair of hypotheses pertained to the effect of political performance-as measured by RPE—on labor's share of national income. This research confirms a positive effect of political performance on LS. During the period examined in this research, changes in RPE appear to predict changes in the trajectory of LS by roughly two years (Figure 4.24). Improvement of political capacity precedes increase in labor's share of national income, whereas deterioration of political capacity leads to a decrease in labor's share. This research therefore confirms the hypothesis that political capacity has been a causal factor in the functional income equality of Argentina and Brazil.

There were two main limitations to this study. The first has to do with the measure of democracy. As explained previously, Polity IV is a relatively minimalist measure of democracy which focuses on the executive branch of government and provides a single score meant to encapsulate the degree of democracy or authoritarianism. For most of the period in question, both countries had the same index score and fit into the same regime category as one another. This makes it difficult to contrast the quality of democracy between the two cases or over time. Given that Argentina and Brazil remained in the category of "democracy" from the time of transition onward according to the Polity Project, this index did not highlight meaningful change over time or nuance in the quality of democracy for the period being studied. A 
multidimensional or more nuanced operationalization of democracy could benefit this research.

The second significant limitation to this research was the dearth of quality data. This is an issue for many underdeveloped countries as well as authoritarian regimes. Simply put, poor states and authoritarian governments seem to provide relatively less complete and less accurate data than do wealthy democracies. This was particularly true of labor and employment statistics, which were only available back to 1992, but was also true of the Corruption Perception Index, which only reached back to 1995.

This research has several policy implications. If it is true, as this study suggests, that political capacity is a causal factor affecting functional income inequality, then efforts to strengthen political institutions and political performance should take primacy over efforts to shore up procedural democracy alone. As de Soto (2000) suggests, a focus on improving property rights and the rule of law would be significant steps toward alleviating poverty and inequality in Argentina and Brazil. In an effort to enhance political capacity, the governments of Argentina and Brazil should make efforts to reach rural and agricultural areas and to incorporate or reduce the informal economy. These efforts should increase political reach and extraction, two components of Relative Political Capacity.

Another policy implication of this research has to do with the model of development that Argentina and Brazil follow. As this research suggests, the neoliberal development model and Washington Consensus failed to prevent economic crisis in 
Argentina and Brazil. This model of development is also argued to increase unemployment and focus on growth and stability of the economy as a whole rather than the plight of the large, poor segment of the working population. Indeed, while no regime studied in this thesis went against the tide of economic liberalization, the regime that corresponded with the most extreme economic opening also suffered from a significant decrease in labor's share of national income ${ }^{6}$. If it is true, as the literature suggests, that poverty and inequality hinder growth and development, then perhaps Argentina and Brazil should consider abandoning or altering their adherence to the Washington Consensus.

This thesis has revealed several areas for further research on the relationship between democratization, political performance, and equitable development. First, as previously stated, the reliance on the Polity IV index to examine the level of democracy in this research lead to a relatively minimalist and executive-oriented understanding of each regime. Further research should consider alternative measures of democracy. As Merkel (2004) points out, simply having free and fair elections is not the same as having a genuine, "embedded" democracy. It is possible that neither Argentina nor Brazil have ever achieved such status, making it difficult to draw a meaningful conclusion with regard to the relationship between democracy and income distribution. Future research would be well served to delve more deeply into the true nature of each supposedly

${ }^{6}$ The Menem Presidency in Argentina oversaw the most rapid increase in the IADB Structural Reform Index (0.41 to 0.63) and also a significant decrease in LS4 (Figure 4.15). 
democratic regime. Such analysis could include World Values Survey data regarding popular preferences for a democratic political system versus the appeal for a strong leader who does not have to bother with a legislative body or elections. Such value preferences would speak to the quality of democracy better than a single index could. It could be possible that there is a stronger relationship between embedded democracy and equitable income distribution than this research was able to unearth.

Another potentially fruitful area of further research would be to test on a larger scale the positive relationship that this study found between political performance and income equality. A large- $\mathrm{N}$, empirically driven analysis could either strengthen or refute the findings of this research, which suggest the degree of governance positively affects an equitable income distribution.

In sum, this work suggests that in the cases of Argentina and Brazil, political performance is a strong determinant of the distribution of income regardless of the type of regime or level of democracy. To the extent that poverty and inequality are endemic to Latin America and cause a great deal of suffering, it is important to make efforts to improve the capability of governments throughout the region. 


\section{Works Cited}

Arceneaux, Craig L. Bounded Missions: Military Regimes and Democratization in the Southern Cone and Brazil. University Park, Penn: Pennsylvania State UP, 2001. Print.

Arestis, Philip. "Washington Consensus and Financial Liberalization." Journal of Post Keynesian Economics 27.2 (2004): 251-71. Print.

"Argentina to Take over Pensions." BBC News. BBC, 21 Oct. 2008. Web. 21 Apr. 2015. Armijo, Leslie Elliott, and Philippe Faucher. "'We Have A Consensus": Explaining Political Support for Market Reforms in Latin America." Latin American Politics and Society 44.2 (2002): 1-40. Web.

Armijo, Leslie Elliott, and Carlos Gervasoni. "Two Dimensions of Democracy and the Economy." Democratization 17.1 (2010): 143-74. Web.

Atkinson, A. B. "Factor Shares: The Principal Problem of Political Economy?" Oxford Review of Economic Policy 25.1 (2009): 3-16. Web

Bellinger, P. T., and M. Arce. "Protest and Democracy in Latin America's Market Era." Political Research Quarterly 64.3 (2010): 688-704. “Corruption Perception Index: In Detail.” Transparency International. n.p. 2013. Web. 20 July 2014.

Bin, Daniel. "The Class Character of Macroeconomic Policies in Brazil of the Real." Critical Sociology 40.3 (2014): 431-449. 
Bueno de Mesquita, Bruce. The Logic of Political Survival. Cambridge, MA: MIT, 2003. Print.

Carranza, M. E. "Poster Child or Victim of Imperialist Globalization? Explaining Argentina's December 2001 Political Crisis and Economic Collapse." Latin American Perspectives 32.6 (2005): 65-89. Web.

Conde, Roberto Cortés. The Political Economy of Argentina in the Twentieth Century. New York: Cambridge UP, 2009. Print.

Corrales, Javier. Presidents without Parties: The Politics of Economic Reform in Argentina and Venezuela in the 1990s. University Park, PA: Pennsylvania State UP, 2002. Print.

de Soto, Hernando. The Mystery of Capital: Why Capitalism Triumphs in the West and Fails Everywhere Else. New York: Basic, 2000. Print.

Diamond, Larry Jay. The Spirit of Democracy: The Struggle to Build Free Societies Throughout the World. New York: Times and Henry Holt, 2008. Print.

"Don't Lie to Me, Argentina." The Economist. The Economist Newspaper, 25 Feb. 2012. Web. 21 Apr. 2015

Flynn, Peter. "Collor, Corruption and Crisis: Time for Reflection." Journal of Latin American Studies 25.2 (May, 1993). 351-371.

Friedman, Milton. Capitalism and Freedom. Chicago: U of Chicago, 1962. Print. 
Gilbert, Jonathan. "Fallout Over Argentine Prosecutor's Death Draws International Tensions." The New York Times. The New York Times, 17 Feb. 2015. Web. 21 Apr. 2015.

Griffin, Keith B. Alternative Strategies for Economic Development. New York: St. Martin's in Association with the OECD Development Centre, 1989. Print.

Guerriero, Marta. "The Labour Share of Income around the World: Evidence from a Panel Dataset." Institute for Development Policy and Management. Development Economics and Public Policy Working Paper Series. WP No, 32 (2012).

Haggard, Stephan, and Robert R. Kaufman. Development, Democracy, and Welfare States: Latin America, East Asia, and Eastern Europe. Princeton: Princeton UP, 2008. Print.

Harrison, A. E. (2002). Has Globalization Eroded Labor's Share? Some Cross-Country Evidence. UC Berkeley and NBER.

Human Development Report 2010. “The Real Wealth of Nations: Pathways to Human Development. United Nations Development Programme, Nov., 2010. Web.

Hunter, Wendy, and Natasha Borges Sugiyama. "Democracy and Social Policy in Brazil: Advancing Basic Needs, Preserving Privileged Interests." Latin American Politics and Society 51.2 (2009): 29-58. Web.

Johnson, D. G. (1954). The Functional Distribution of Income in the United States, 18501952. The Review of Economics and Statistics, 36, 175-182. 
Jong-A-Pin, Richard, and Jakob De Haan. "Political Regime Change, Economic Liberalization And growth Accelerations." Public Choice. 146.1-2 (2010): 93115.

Jouet, Mugambi. "The Failed Invigoration of Argentina's Constitution: Presidential Omnipotence, Repression, Instability, and Lawlessness in Argentine History." The University of Miami Inter-American Law Review 39.3 (2008): 409-62. JSTOR. Web. 17 Feb. 2015.

Kingstone, Peter R. The Political Economy of Latin America: Reflections on Neoliberalism and Development. New York: Routledge, 2011. Print.

Kravis, I. B. (1959). Relative Income Shares in Fact and Theory. The American Economic Review, 49, 917-949.

Kugler, Jacek, and Ronald L. Tammen. The Performance of Nations. Lanham: Rowman \& Littlefield, 2012. Print.

Lora, Eduardo. "Structural Reforms in Latin America: What Has Been Reformed and How to Measure It (Updated version).” IDB Working Paper Series. No. IDB-WP346 (Dec., 2012).

Maia, Alexandre Gori, and Esther Menezes. "Economic Growth, Labor and Productivity in Brazil and the United States: a Comparative Analysis.” Brazilian Journal of Political Economy 34.2 (April-June 2014): 212-229.

McMahon, Edward, and Emilie Kornheiser. "Assessing the Assessors: Correlating Democracy Methodologies." Social Indicators Research 97.2 (2009): 269-77. 
Medialdea, Bibiana. "Brazil: An Economy Caught in a Financial Trap (1993-2003)." Revista De Economia Política 33.3 (2013): 427-45.

Merkel, Wolfgang. "Embedded and Defective Democracies.” Democratization 11.5 (December 2004): 33-58. Print.

Moreno-Brid, Juan Carlos. "The Washington Consensus: A Latin American Perspective Fifteen Years Later." Journal of Post Keynesian Economics 27.2 (2004): 345-65. Print.

Munck, G. L., and J. Verkuilen. "Conceptualizing and Measuring Democracy: Evaluating Alternative Indices." Comparative Political Studies 35.1 (2002): 5-34. Web.

Nassif, André, and Carmem Feijó. "Liberal versus Neo-developmental Convention to Growth: Why Has Brazil Shown a Poor Performance since the 1980s?" Revista De Economia Política 33.4 (2013): 555-76.

Pang, Eul-Soo. The International Political Economy of Transformation in Argentina, Brazil, and Chile since 1960. Houndmills, Basingstoke, Hampshire: Palgrave Macmillan, 2002. Print.

Panizza, Francisco. "Neopopulism and its Limits in Collor's Brazil.” Bulletin of Latin American Research. 19.2 (Apr., 2000): 177-192.

Pereira, Luiz Carlos Bresser, José María. Maravall, and Adam Przeworski. Economic Reforms in New Democracies: A Social-democratic Approach. Cambridge: Cambridge UP, 1993. Print. 
Piketty, Thomas. Capital in the Twenty-First Century. Cambridge: The Belknap Press of Harvard University Press, 2014. Print.

Przeworski, Adam, and Fernando Limongi. "Modernization: Theories and Facts." World Politics 49.02 (1997): 155-83. Web.

Remmer, Karen L. "The Politics of Economic Policy and Performance in Latin America." Journal of Public Policy 22.01 (2002). Web.

Remmer, Karen L. "The Political Economy of Patronage: Expenditure Patterns in the Argentine Provinces, 1983-2003." The Journal of Politics 69.02 (2007). Web.

Sen, Amartya. "Poor, Relatively Speaking." Oxford Economic Papers 35.2 (1983): 15369. Print.

Stiglitz, J. E. "Rethinking Development Economics." The World Bank Research Observer 26.2 (2011): 230-36. Web.

Tammen, Ronald L. Power Transitions: Strategies for the 21st Century. New York: Chatham House, 2000. Print.

“The Polity Project.” Center for Systemic Peace. n.p., n.d. Web. 20 July 2014.

"Transparency International - The Global Anti-Corruption Coalition." Transparency International - The Global Anti-Corruption Coalition. Web. 03 Apr. 2015.

Tsebelis, George. "Decision Making in Political Systems: Veto Players in Presidentialism, Parliamentarism, Multicameralism and Multipartyism."British Journal of Political Science 25.03 (1995): 289. Print. 
Umar Wahedi, Ayesha, "Capital Flows, Political Performance, and Development" (2011). Dissertations and Theses. Paper 217.

"Unequal Income Distribution, 'almost unaffected by economic reforms," Latin American Regional Reports: Brazil Report (24 April 2001), p. 1.

Walker, Christopher. “Toward Democratic Consolidation? The Argentine Supreme Court, Judicial Independence, and the Rule of Law." Florida Journal of International Law 18.3 (2006): 745-804. Print.

Weyland, Kurt Gerhard. The Politics of Market Reform in Fragile Democracies: Argentina, Brazil, Peru, and Venezuela. Princeton: Princeton UP, 2002. Print.

Wilhelm, Paul G. "International Validation of the Corruption Perceptions Index: Implications for Business Ethics and Entrepreneurship Education.” Journal of Business Ethics 35.3 (Feb., 2002): 177-189. Web.

Wilkinson, Richard G., and Kate Pickett. The Spirit Level: Why Greater Equality Makes Societies Stronger. New York: Bloomsbury, 2010. Print.

Wogart, Jan Peter. "Global Booms and Busts: How Is Brazil's Middle Class Faring?" Revista De Economia Política 30.3 (2010): 381-400.

Wolff, H., Chong, H. and Auffhammer, M. (2011), Classification, Detection and Consequences of Data Error: Evidence from the Human Development Index. The Economic Journal, 121: 843-870. 
Wylde, Christopher. "State, Society and Markets in Argentina: The Political Economy of Neodesarrollismo under Néstor Kirchner, 2003-2007."Bulletin of Latin American Research 30.4 (2011): 436-52. Web. 